\title{
Dissolution of Neptunium Oxide Residues
}

\author{
Edward A. Kyser
}

January 12, 2009

Savannah River National Laboratory Savannah River Nuclear Solutions

Aiken, SC 29808

Prepared for the U.S. Department of Energy Under Contract Number DE-AC09-08SR22470

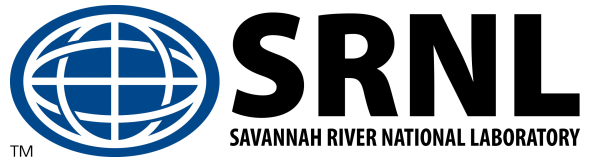




\section{DISCLAIMER}

This work was prepared under an agreement with and funded by the U.S. Government. Neither the U. S. Government or its employees, nor any of its contractors, subcontractors or their employees, makes any express or implied:

1. warranty or assumes any legal liability for the accuracy, completeness, or for the use or results of such use of any information, product, or process disclosed; or

2. representation that such use or results of such use would not infringe privately owned rights; or 3. endorsement or recommendation of any specifically identified commercial product, process, or service.

Any views and opinions of authors expressed in this work do not necessarily state or reflect those of the United States Government, or its contractors, or subcontractors. 


\title{
Dissolution of Neptunium Oxide Residues
}

\author{
Edward A. Kyser
}

January 12, 2009

\section{Author}

Original signed by E. A. Kyser on January 13, 2009

E. A. Kyser, SRNL Separations Science Programs $\quad$ Date

\section{Technical Reviewer}

Original signed by Mark L. Crowder on January 14, 2009

M. L. Crowder, SRNL Separations Science Programs

Date

\section{Customer Concurrence}

Original signed by Jeff Schaade on January 14, 2009

J. B. Schaade, HMD HB-Line Engineering Manager

Date

\section{Management Approvals}

Original signed by Samuel D. Fink on January 14, 2009

S. D. Fink, SRNL Separations Science Programs Manager

Date

Original signed by Sharon L. Marra on January 14, 2009

S. L. Marra, SRNL E\&CPT Research Programs Manager

Date 
SRNL-STI-2008-00523, Rev 0

Page intentionally left blank 


\section{Table of Contents}

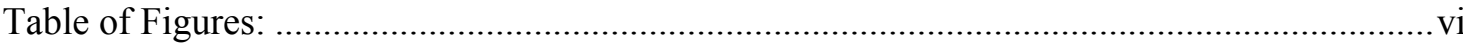

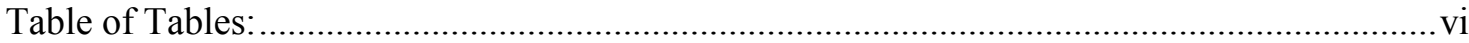

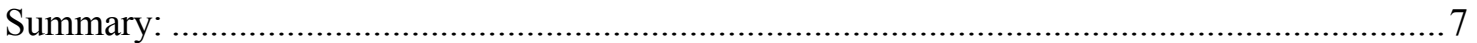

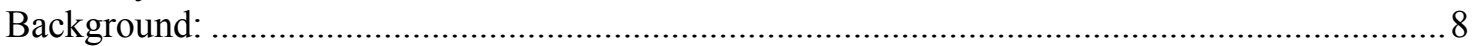

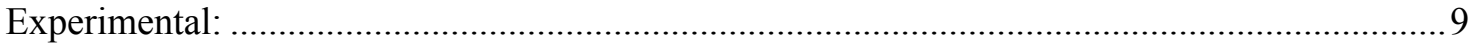

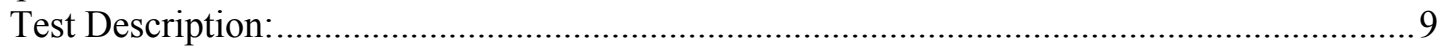

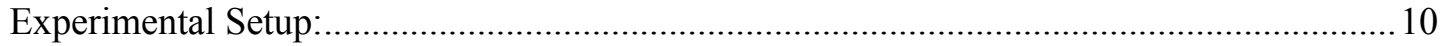

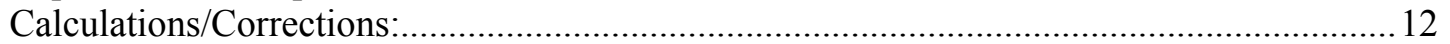

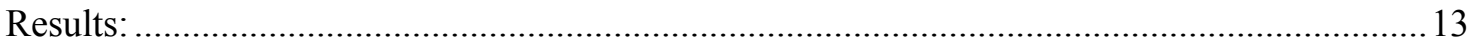

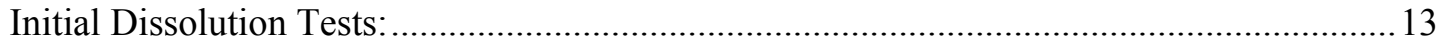

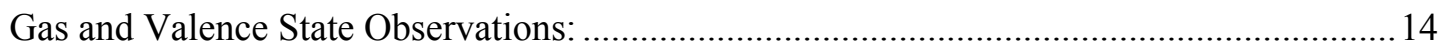

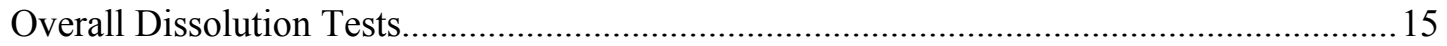

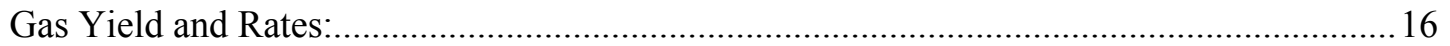

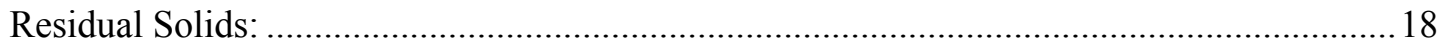

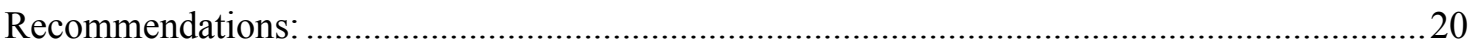

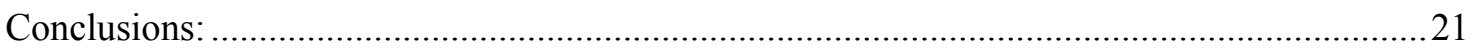

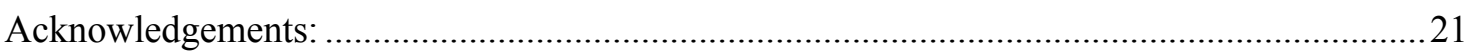

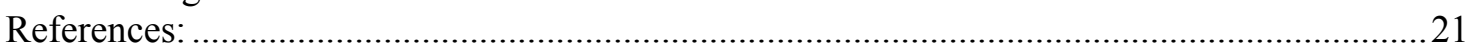

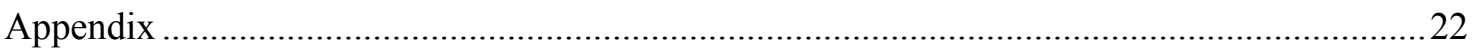




\section{Table of Figures:}

Figure 1. Experimental Setup............................................. 10

Figure 2. Equipment: a) Dissolver \& Condenser Apparatus, ...................... 11

b) Gas collection and measurement by water displacement, ...... 11

c) Gas Sampling bulbs with $\mathrm{NO}, \mathrm{N}_{2} \mathrm{O}, \mathrm{NO}_{2}$ present. ............ 11

Figure 3. Correction due to Pressure Head. .................................... 12

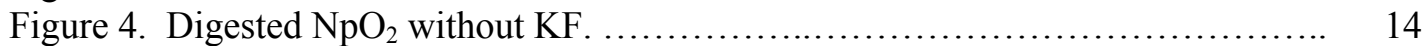

Figure 5. NpCo Vial 898 Dissolution Test. ........................................ 14

Figure 6. Temperature Profile over Time for $110 \mathrm{~mL}$ Dissolution Experiments. ........ 16

Figure 7. Standard Gas Volume Evolved over Time. ............................ 16

Figure 8. Gas Yield over Time. ............................................. 16

Figure 9. Molar Gas Yield Rate over Time. ................................... 17

Figure 10. Rate of Gas Evolution per kg of Bulk Oxide over Time. ................ 17

Figure 11. Solids from Vial 895 (Sweepings I) Dissolution. ........................ 19

Figure 12. Solids from Vial 898 (NpCo) Dissolution. ............................. 19

Figure 13. Solids from Vial 946 (Sweepings II) Dissolution. ........................ 19

Figure 14. Solids from Vial $200\left(650^{\circ} \mathrm{C} \mathrm{NpO}_{2}\right)$ Dissolution. ........................ 19

Figure 15. Solids from Vial $838\left(1000^{\circ} \mathrm{C}\right.$ TGA $\left.\mathrm{NpO}_{2}\right)$ Dissolution. .................. 19

Figure 16. Solids from Vial 946 8MF1 Dissolution. .................................. 19

\section{Table of Tables:}

Table 1. Pressure for Gas Collection System. .................................. 12

Table 2. Gas Analysis Test with a Known Standard Gas. .......................... 13

Table 3. Np Dissolution Test Conditions. ..................................... 15

Table 4. Gas Analysis Results for Dissolution of $\mathrm{NpO}_{2}$ Samples.................... 17

Table 5. XRD and SEM Characterization of Np Dissolution Residues. ............... 18

Table 6. Aluminum Nitrate Solubility Test. .................................... 20

Table 7. Gas Results for Pure $\mathrm{NpO}_{2}$ Material. ..................................... 23

Table 8. Gas Results for Pure $\mathrm{NpO}_{2}$ Material. ................................... 23

Table 9. Gas Results for NpCo Source Material. .................................. 24

Table 10. Gas Results for Np Sweepings Material. ............................... 24

Table 11. Gas Results for Np Sweepings Material. .............................. 25

Table 12. Gas Results for Np Sweepings Material. .............................. 25 


\title{
Dissolution of Neptunium Oxide Residues
}

\author{
by \\ Edward A. Kyser \\ Savannah River National Laboratory \\ Environmental and Chemical Technology Directorate
}

January 12, 2009

\section{Summary:}

This report describes the development of a dissolution flowsheet for neptunium (Np) oxide $\left(\mathrm{NpO}_{2}\right)$ residues (i.e., various $\mathrm{NpO}_{2}$ sources, HB-Line glovebox sweepings, and Savannah River National Laboratory (SRNL) thermogravimetric analysis samples). Samples of each type of materials proposed for processing were dissolved in a closed laboratory apparatus and the rate and total quantity of off-gas were measured. Samples of the off-gas were also analyzed. The quantity and type of solids remaining (when visible) were determined after postdissolution filtration of the solution.

Recommended conditions for dissolution of the $\mathrm{NpO}_{2}$ residues are:

Solution Matrix and Loading: $\sim 50 \mathrm{~g} \mathrm{~Np} / \mathrm{L}$ (750 g Np in $15 \mathrm{~L}$ of dissolver solution), using $8 \mathrm{M}$ nitric acid $\left(\mathrm{HNO}_{3}\right), 0.025 \mathrm{M}$ potassium fluoride $(\mathrm{KF})$ at greater than $100{ }^{\circ} \mathrm{C}$ for at least 3 hours.

Off-gas: Analysis of the off-gas indicated nitric oxide $(\mathrm{NO})$, nitrogen dioxide $\left(\mathrm{NO}_{2}\right)$ and nitrous oxide $\left(\mathrm{N}_{2} \mathrm{O}\right)$ as the only identified components. No hydrogen $\left(\mathrm{H}_{2}\right)$ was detected. The molar ratio of off-gas produced per mole of $\mathrm{Np}$ dissolved ranged from 0.25 to 0.4 moles of gas per mole of $\mathrm{Np}$ dissolved. A peak off-gas rate of $\sim 0.1 \mathrm{scfm} / \mathrm{kg}$ bulk oxide was observed.

Residual Solids: Pure $\mathrm{NpO}_{2}$ dissolved with little or no residue with the proposed flowsheet but the NpCo and both sweepings samples left visible solid residue after dissolution. For the NpCo and Part II Sweepings samples the residue amounted to $\sim 1 \%$ of the initial material, but for the Part I Sweepings sample, the residue amounted to $\sim 8 \%$ of the initial material. These residues contained primarily aluminum (Al) and silicon (Si) compounds that did not completely dissolve under the flowsheet conditions. The residues from both sweepings samples contained minor amounts of plutonium $(\mathrm{Pu})$ particles. Overall, the undissolved $\mathrm{Np}$ and $\mathrm{Pu}$ particles in the residues were a very small fraction of the total solids. 


\section{Background:}

Currently housed in HB-Line inventory is approximately $1.5-2 \mathrm{~kg}$ of neptunium oxide $\left(\mathrm{NpO}_{2}\right)$ of insufficient purity to ship as product. This material includes 'NpCo' (a term designating combined legacy $\mathrm{NpO}_{2}$ standards), sweepings material from mechanical line processing and lab sample returns. Additional $\mathrm{NpO}_{2}$ samples returns from the SRNL are also planned for inclusion in this inventory. HB-Line Phase I is identified as the facility for dissolution of these materials. HB-Line Phase II recently finished production of $\mathrm{NpO}_{2}$ material and is soon to begin the 'flush and lay-up' process. To transfer this 'off-specification' material to $\mathrm{H}$ Canyon with other Phase II processing losses, the material must be dissolved.

'NpCo' material was combined from legacy $\mathrm{NpO}_{2}$ sources several years ago. According to the Materials Control and Accountability information, the material traces to the early 1980's in the Old HB-Line vault. ${ }^{1}$ Procedures completed during packaging indicate visual inspection confirmed each portion is oxide. All indications are that this material is $\mathrm{NpO}_{2}$ produced in Old HB-Line by an oxalate precipitation process very similar to the process operated in $\mathrm{HB}$-Line Phase II today. Previous characterization found that the ' $\mathrm{NpCo}$ ' material contained $\sim 6 \mathrm{wt} \%$ insoluble sodium, aluminum, and silicon compounds ${ }^{2,3,4}$. These contaminants are likely from desiccants used in the original sources.

Np sweepings are materials produced in HB-Line Phase II that were retained due to their significant $\mathrm{Np}$ content but were not shippable as pure $\mathrm{NpO}_{2}$ product. The Phase II process produced $\mathrm{NpO}_{2}$ from calcination at $\sim 635^{\circ} \mathrm{C}$ from the product of an oxalate precipitation process. Therefore, the bulk of the sweepings materials are oxides but residue swept from the floor of the glovebox was probably included in the sweepings material. Unused $\mathrm{NpO}_{2} \mathrm{sam}^{-}$ ples and precipitator cleanout residues were also retained as sweepings.

SRNL sample returns are all materials that were produced in HB-Line Phase II during either the Part I or Part II campaigns. Some of this material was heated to higher temperatures during TGA or BET analyses $\left(1000\right.$ to $\left.1300{ }^{\circ} \mathrm{C}\right)$ and may exhibit different dissolution behavior as higher temperatures reduce the surface area of the oxide.

The dissolution of $\mathrm{NpO}_{2}$ by nitric acid is expected to produce $\mathrm{NO}_{\mathrm{x}}$ gases due to the oxidation of $\mathrm{Np}^{4+}$ to $\mathrm{Np}^{5+}$ and $\mathrm{Np}^{6+}$. HB-Line controls the dissolver purge rate to limit flammable gas concentrations during dissolution. No $\mathrm{H}_{2}$ off-gas would be expected to be produced if the materials are only oxides ${ }^{5,6}$. The dissolution of $\mathrm{NpO}_{2}$ has not been a routine activity in HBLine but flowsheets for the recovery of small quantities of $\mathrm{NpO}_{2}$ are described in internal site documents $^{7,8}$.

The $\mathrm{NpO}_{2}$ considered for dissolution consists of $\mathrm{Np}$ Part I Sweepings (accumulated August 2004 through September 2006), Np Part II Sweepings (accumulated January 2008 through November 2008), 'NpCo' and SRNL sample return oxides. It is expected that a total of $\sim 2 \mathrm{~kg}$ of $\mathrm{Np}$ oxide will be dissolved in HB-Line Phase I with a batch size of $\sim 1 \mathrm{~kg}$ of $\mathrm{Np}$. The target $\mathrm{Np}$ concentration in the dissolver is $\sim 50 \mathrm{~g} \mathrm{~Np} / \mathrm{L}^{9,10}$. A single dissolution flowsheet for processing all the identified $\mathrm{Np}$ oxides in a Phase I dissolver using 2-12 M nitric acid 
with up to $0.1 \mathrm{M} \mathrm{KF}$ is preferred. The dissolver is assumed to operate at $>100{ }^{\circ} \mathrm{C}$ with a $20 \mathrm{scfm}$ purge rate. HB-Line Engineering requested that the flowsheet dissolve a high percentage of the material (although it is expected that some insoluble silicate compounds may be present). SRNL was also requested to measure the total gas generation rate during the dissolution and the percent residual solids for each class of materials.

Three classes of materials are identified for testing: 1) 'NpCo' (combined legacy Np oxide standards, Vial 898 sample received April 27, 2007), 2) Np Sweepings (Part I Vial 895 received April 27, 2007, and Part II Vial 946 received December 1, 2008, and 3) SRNL sample returns (Vials 838 \& 951 received from M. L. Crowder, October 7, 2008, Vial 200 received from B. C. Hill, November 9, 2005). The calcination temperature history of these materials varies and it was anticipated that oxides heated to higher temperatures might have different dissolution characteristics. (Vials 838 and 951 contain TGA materials heated to $1000^{\circ} \mathrm{C}$ and $1300^{\circ} \mathrm{C}$ respectively which should be bounding materials for testing.) An additional sample of Part II Np Sweepings (Vial 946) was tested due to HB-Line concerns about the uniformity of the sweepings materials.

HB-Line will use $34 \mathrm{wt} \%$ aluminum nitrate solution to complex the fluoride used for dissolution at the ratio of three moles of Al per mole of fluoride. HB-Line requested demonstration that Al solubility downstream of the dissolution step would not be exceeded.

\section{Experimental:}

Test Description: Small samples of $\mathrm{NpO}_{2}$ were dissolved in acid solution in two types of tests. Simple batch dissolution tests were performed to determine appropriate conditions for dissolution of the materials without leaving significant solid residues. Many of these tests were performed in air, but the later tests were performed in argon. The completeness of dissolution was primarily judged based on visual observations for solids after filtration. UVvisible spectroscopic examination of solution samples taken over time also looked for changes in $\mathrm{Np}$ concentration and valence state. Post-dissolution filtration of the solution ( $0.45 \mu \mathrm{m}$ membrane filter) after cooling was used to determine the quantity of residual solids that remained.

When determination of off-gas volumes and rates was required, the dissolution apparatus was operated as a closed system. This second type of dissolution test was performed with a sample gas bag connected to the closed system. Because $\mathrm{NO} / \mathrm{NO}_{2}$ gases were anticipated to be a significant component of the off-gas, the system was flushed at the beginning of each test with inert argon (Ar) gas. Air, especially oxygen $\left(\mathrm{O}_{2}\right)$, was flushed from the apparatus to prevent reaction with $\mathrm{NO}$ to form additional $\mathrm{NO}_{2}$. No liquid sampling of this system was performed until after the gas generation slowed and gas samples (if needed) were pulled for gas chromatography (GC) analysis. Gas volumes were determined in these experiments by collection of the off-gas in the sample bag and measurement of the volume of water displaced as the bag inflated. Gas samples were collected while the system was at temperature.

Previous testing observed the evolution of brown $\mathrm{NO}_{2}$ fumes during dissolution of $\mathrm{NpO}_{2}$. These gases are products from the oxidation of $\mathrm{Np}^{4+}$ to $\mathrm{Np}^{5+}$ and $\mathrm{Np}^{6+}$. Depending on the chemical conditions during dissolution $\mathrm{Np}$ may exist in any or all of these oxidation states. 
When composition determination of the gas samples was required, the analysis was performed by the Analytical Development (AD) department on a Hewlett Packard model 5890 gas chromatograph (GC) equipped with a 60/80 Carboxen 1000 column (15 feet X 1/8 inch stainless steel, $2.1 \mathrm{~mm}$ ID) and thermal conductivity detector (TCD). Calibration was carried out prior to and after the sample analyses using Scott Gas Mix 218, as well as calibration verification using blank air. Samples were normally analyzed in duplicate for confirmation of results but in some cases only a single determination on duplicate samples was performed. Argon carrier gas was used.

Experimental Setup: The experimental setup for all gas collection testing consists of a 125 $\mathrm{mL}$ 4-port boiling flask fitted with a small condenser. Tygon ${ }^{\circledR}$ tubing $(0.125$ in. ID) con-

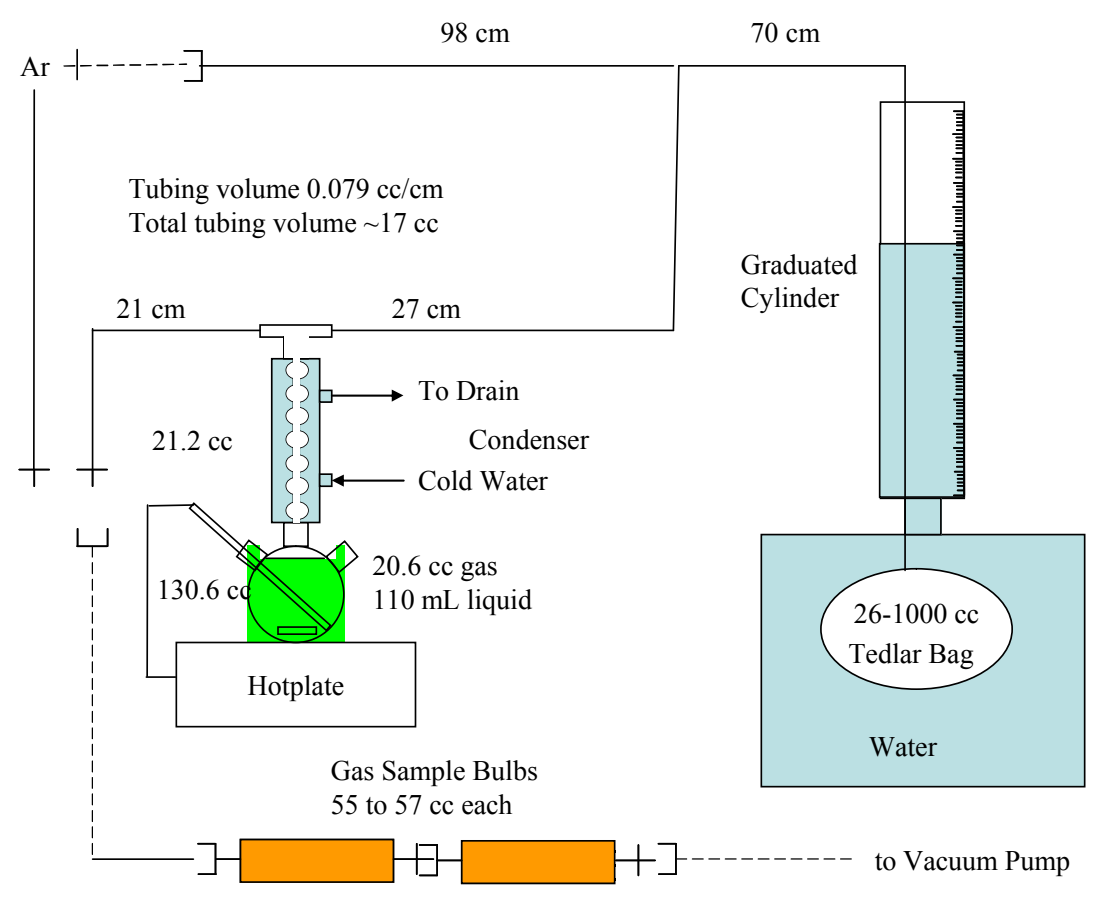

Figure 1. Experimental Setup. nected a Swagelok ${ }^{\circledR}$ "T" to the 1-L Tedlar® gas bag. The gas bag was submerged in a $\sim 3-\mathrm{L}$ glass kettle with a $\sim 325-\mathrm{mL}$ graduated cylinder installed on top. Two other Tygon ${ }^{\circledR}$ lines allow connection to the argon supply and gas sample bulbs. These lines and the gas sample bulbs are fitted with quickconnect fittings that seal when disconnected so that the system can be kept closed. The 1-L

Tedlar ${ }^{\circledR}$ bag allows for a significantly larger quantity of gas than is anticipated in any experiment (with up to $9 \mathrm{~g}$ of oxide). This bag will burst at 2 to 2.5 psig providing for a safefailure mechanism ${ }^{11}$. The apparatus was repeatedly filled and purged with argon before each experiment. A leak-check step was later incorporated into the procedure as part of the argon purge after the apparatus was assembled and loaded with solution and oxide. Gas sample bulbs were alternatively filled with argon and evacuated with a small vacuum pump capable of evacuating the bulbs to $25-27 \mathrm{in}$. of $\mathrm{Hg}$. Argon was chosen due to its inertness and the consideration that any air in-leakage would be readily detected by the presence of oxygen or nitrogen. Argon is also the carrier gas for the GC method used in the gas analysis. Gas samples were taken after off-gas generation was complete and with the dissolver system at temperature. A sketch of the experimental setup showing approximate tubing lengths and volumes is shown in Figure 1. Photos of the actual apparatus follow in Figures 2a, 2b, and 2c. 

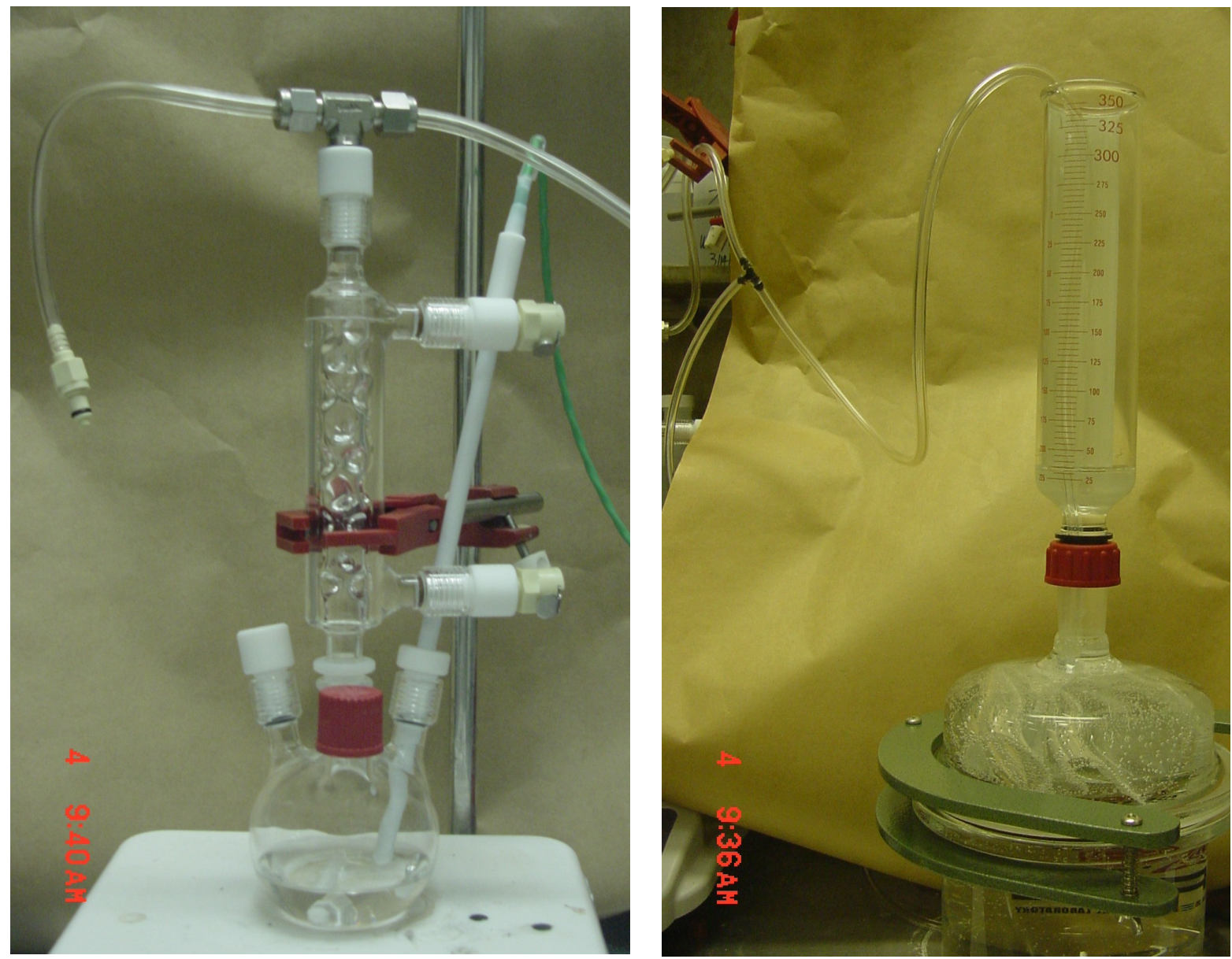

a)

b)

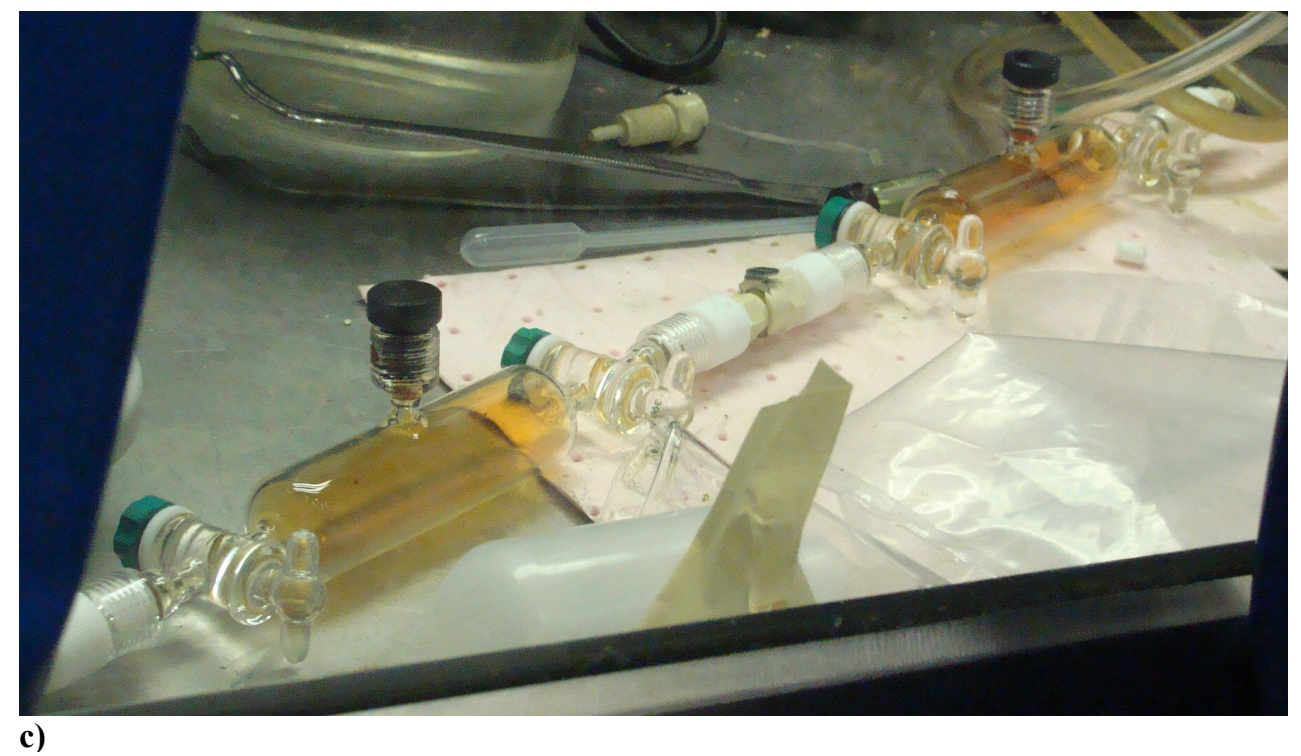

Figure 2. Equipment: a) Dissolver \& Condenser Apparatus, b) Gas Collection and measurement by Water Displacement, c) Gas Sampling Bulbs with $\mathrm{NO}, \mathrm{N}_{2} \mathrm{O}, \mathrm{NO}_{2}$ Present. 
Experiments that were only directed at investigating dissolution conditions were performed with a relatively small volume of solution in the boiling flask (typically $33 \mathrm{~mL}$ ). Tests performed with a relatively large volume of vapor space in the boiling flask resulted in a significant volume of expansion gas due to the increased partial pressure of water vapor and displacement of the argon gas as the solution warmed. Experiments directed at gas volume measurement were performed with a relatively large volume of solution in the boiling flask (typically $110 \mathrm{~mL}$ ). This volume of solution left a relatively small volume of vapor space ( 20.6 cc). Tests with $12 \mathrm{M} \mathrm{HNO}_{3}$ but limited to $100{ }^{\circ} \mathrm{C}$ had a smaller heat-up volume effect due to the smaller partial pressures generated.

Calculations/Corrections: Correction of the gas volume for the liquid pressure head, the gas temperature and the volume displaced by the collection tubing in the graduate were required to convert the measured gas volume to Standard Temperature and Pressure (STP; 1 atm, $0{ }^{\circ} \mathrm{C}$ ). Atmospheric pressure was assumed constant at $1 \mathrm{~atm}$. The pressure correction due to water pressure on the gas bag varied linearly with the amount of gas collected as shown in Table 1 and Figure 3. The gas temperature correction was made based on a meas-

Table 1. Pressure Correction for Gas Collection System.

\begin{tabular}{ccc}
$\begin{array}{c}\mathrm{V} \\
\mathrm{cc}\end{array}$ & $\begin{array}{c}\mathrm{P} \\
\text { in. } \mathrm{H}_{2} \mathrm{O}\end{array}$ & $\mathrm{P}^{*}$ \\
\hline 25 & 4.6 & $1.1 \%$ \\
42 & 5.0 & $1.2 \%$ \\
86 & 6.0 & $1.5 \%$ \\
130 & 7.0 & $1.7 \%$ \\
174 & 8.0 & $2.0 \%$ \\
218 & 9.0 & $2.2 \%$ \\
262 & 10.0 & $2.5 \%$ \\
306 & 11.0 & $2.7 \%$ \\
350 & 12.0 & $2.9 \%$ \\
\hline $\mathrm{P}=4.0579+\mathrm{V}^{*} 0.0227$ \\
$\mathrm{P} *=\mathrm{P} / 12 / 33.899$ \\
\hline
\end{tabular}

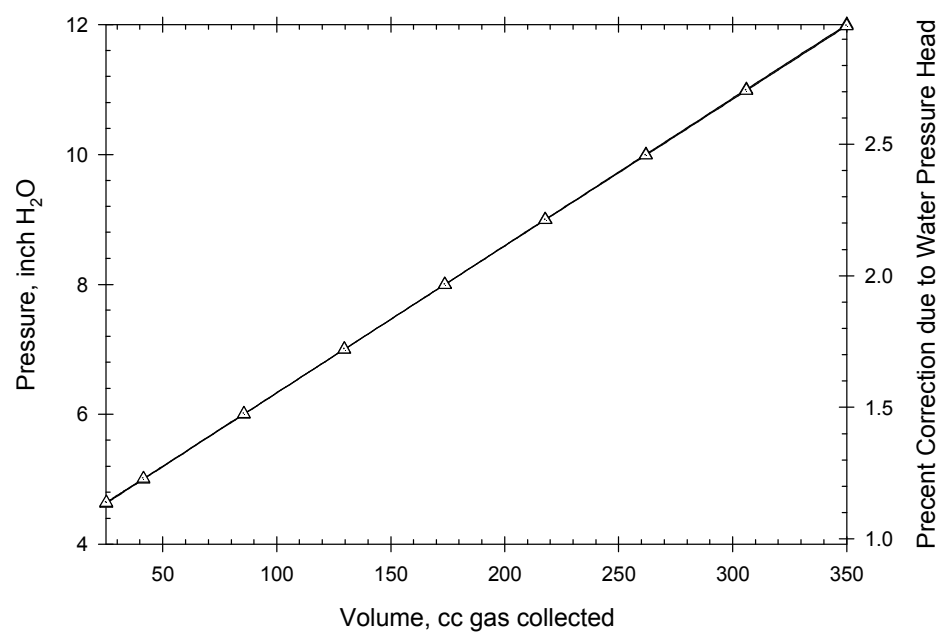

Figure 3. Correction due to Pressure Head.

ured temperature of the laboratory (i.e., the gas bag was placed after the cooling condenser) as a direct measurement of the gas was not readily performed. The laboratory temperature varied from 22 to $25^{\circ} \mathrm{C}$ during the performance of this work. The water in the gas displacement apparatus in the glovebox was assumed to closely track the laboratory temperature. The gas volume was measured by the change in the water volume in the graduated cylinder (Figure 2b). A correction of the gas volume for the tubing volume was a constant reduction of $1.825 \%$ (based on the ratio of the cross-sectional areas of 0.25 in. OD Tygon ${ }^{\circledR}$ tubing to the $4.7 \mathrm{~cm}$ ID graduated cylinder). 


\section{Results:}

Collection Test with Gas Standard: An experiment was performed to demonstrate the ability to accurately retain, sample and analyze for $\mathrm{H}_{2}$. In this test $150 \mathrm{cc}$ of a known standard gas mixture was injected into a clean duplicate of the glovebox apparatus using a 50-cc gas syringe. This gas was taken from a partially filled Tedlar® gas bag to ensure that the gas was at atmospheric pressure. The dissolver apparatus contained $110 \mathrm{~mL}$ of $8 \mathrm{M} \mathrm{HNO}_{3}$ and was previously purged with argon to eliminate air. The initial gas volume of the apparatus was estimated based on a combination of measurements and calculations to be $84.9 \mathrm{cc}$ which would dilute the known standard gas $(150 \mathrm{cc})$ with argon to $64 \%$ of its original concentration. The hotplate was turned on and the apparatus was heated similar to that done in the dissolution experiments. After 1 hour (including heating time), a pair of argon-flushed and evacuated gas sample bulbs was connected to the apparatus and a pair of duplicate gas samples were collected with the apparatus at temperature. These samples were submitted for gas analysis by GC along with an undiluted sample of the known standard gas. The results are shown in Table 2. $\mathrm{CO}_{2}$ was not detected although it was present at the 0.64 to $1 \%$ level (probably due to $\mathrm{CO}_{2}$ 's longer retention time). $\mathrm{H}_{2}$ was reported at the expected value within the $20 \%$ uncertainty. $\mathrm{O}_{2}$ was consistently reported at 30 to $50 \%$ of the expected value. Although the uncertainties are significant, this test demonstrated the ability of the experimental apparatus, sampling methods and analytical procedures to collect and quantify $\mathrm{H}_{2}$ and other atmospheric gases.

Table 2. Gas Analysis Test with a Known Standard Gas ${ }^{a}$.

\begin{tabular}{lccccccccc}
\hline & & $\mathrm{H}_{2}$ & $\mathrm{O}_{2}$ & $\mathrm{~N}_{2}$ & $\mathrm{NO}$ & $\mathrm{N}_{2} \mathrm{O}$ & $\mathrm{CO}$ & $\mathrm{CO}_{2}$ & \\
\cline { 1 - 7 } $\mathrm{H}_{2}$ Std Known & Lot\# 607403L & 1 & 1 & 95 & 0 & 0 & 1 & 1 & \\
$\mathrm{H}_{2}$ Std Analyzed & 300255212 & 1.2 & 0.31 & 90 & $<0.1$ & $<0.1$ & 1.3 & & \\
\hline & & $\mathrm{H}_{2}$ & $\mathrm{O}_{2}$ & $\mathrm{~N}_{2}$ & $\mathrm{NO}$ & $\mathrm{N}_{2} \mathrm{O}$ & $\mathrm{CO}$ & $\mathrm{CO}_{2}{ }^{b}$ & $\mathrm{Ar}^{b}$ \\
\hline Diluted $\mathrm{H}_{2}$ Std & Calc & 0.64 & 0.64 & 61.05 & 0.00 & 0.00 & 0.64 & 0.64 & 36 \\
$\mathrm{H}_{2}$ calibration \#1 & 300255136 & 0.77 & 0.22 & 62 & $<0.1$ & $<0.1$ & 1 & & \\
$\mathrm{H}_{2}$ calibration \#2 & 300255137 & 0.67 & 0.33 & 60 & $<0.1$ & $<0.1$ & 0.87 & & \\
\hline
\end{tabular}

${ }^{a}$ Units are volume percent.

${ }^{b}$ Argon and $\mathrm{CO}_{2}$ concentrations are calculated by dilution.

Initial Dissolution Tests: Initial experiments were performed to dissolve pure $\mathrm{NpO}_{2}$ in 12 $\mathrm{M} \mathrm{HNO}_{3}$ based on the prior process reports ${ }^{7,8}$. Although $\mathrm{KF}$ was typically used in the prior flowsheets, it was thought that KF might not be necessary to dissolve $\mathrm{NpO}_{2}$. However, attempts to dissolve pure $\mathrm{NpO}_{2}$ samples without $\mathrm{KF}$ did not give reproducible results. In several tests without $\mathrm{KF}$ in $12 \mathrm{M} \mathrm{HNO}_{3}$ significant $\mathrm{NpO}_{2}$ remained after 2 to 5 hours at $100{ }^{\circ} \mathrm{C}$. The solids changed color during this time and turned from darker green to yellow-green (Figure 4). An X-ray diffraction (XRD) analysis of the solids showed them to be $\mathrm{NpO}_{2}$ but the color and appearance were very different from that of the starting material. After digestion in $12 \mathrm{M} \mathrm{HNO}_{3}$, solid $\mathrm{KF}$ (equivalent to 0.08 to $0.1 \mathrm{M} \mathrm{KF}$ ) was added to the hot solution and dissolution of the $\mathrm{NpO}_{2}$ occurred with 5 to $30 \mathrm{~s}$ (noted in Table 3 as KF delay). This sort of rapid dissolution behavior was repeatedly observed even though several attempts at dissolution without KF did appear successful. Based on the inconsistent dissolution of $\mathrm{NpO}_{2}$ without KF, further attempts to avoid KF usage were not pursued. However, lower KF and acid concentrations were attempted with success. Dissolution conditions of $8 \mathrm{M} \mathrm{HNO}_{3}$ with 


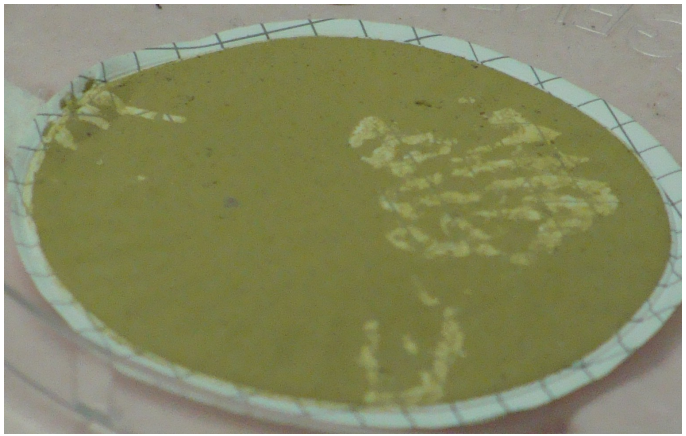

Figure 4. Digested $\mathrm{NpO}_{2}$ without KF.
$0.025 \mathrm{M} \mathrm{KF}$ at $100{ }^{\circ} \mathrm{C}$ for $<1$ hour gave consistent dissolution of pure $\mathrm{NpO}_{2}$ calcined at 650 , 1000 , and $1300{ }^{\circ} \mathrm{C}$ without any significant evidence of residual solids.

Gas and Valence State Observations: During the initial heating of the dissolver flask, brown $\mathrm{NO}_{2}$ fumes were not observed until the temperature of the solution reached $\sim 70-90{ }^{\circ} \mathrm{C}$. Above $90{ }^{\circ} \mathrm{C}$, the brown color was very noticeable in the condenser (see Figure 5). Similar gassing behavior was observed when a mixture of $\mathrm{Np}^{4+}$ and $\mathrm{Np}^{5+}$ solution (without any valence stabilizers) in $12 \mathrm{M} \mathrm{HNO}_{3}$ was heated in the apparatus. It was not determined if the $\mathrm{NpO}_{2}$ was first dissolved and then oxidized to $\mathrm{Np}^{5+}$ and $\mathrm{Np}^{6+}$ or if oxidation was part of the dissolution behavior. Sampling and measurement of the solution

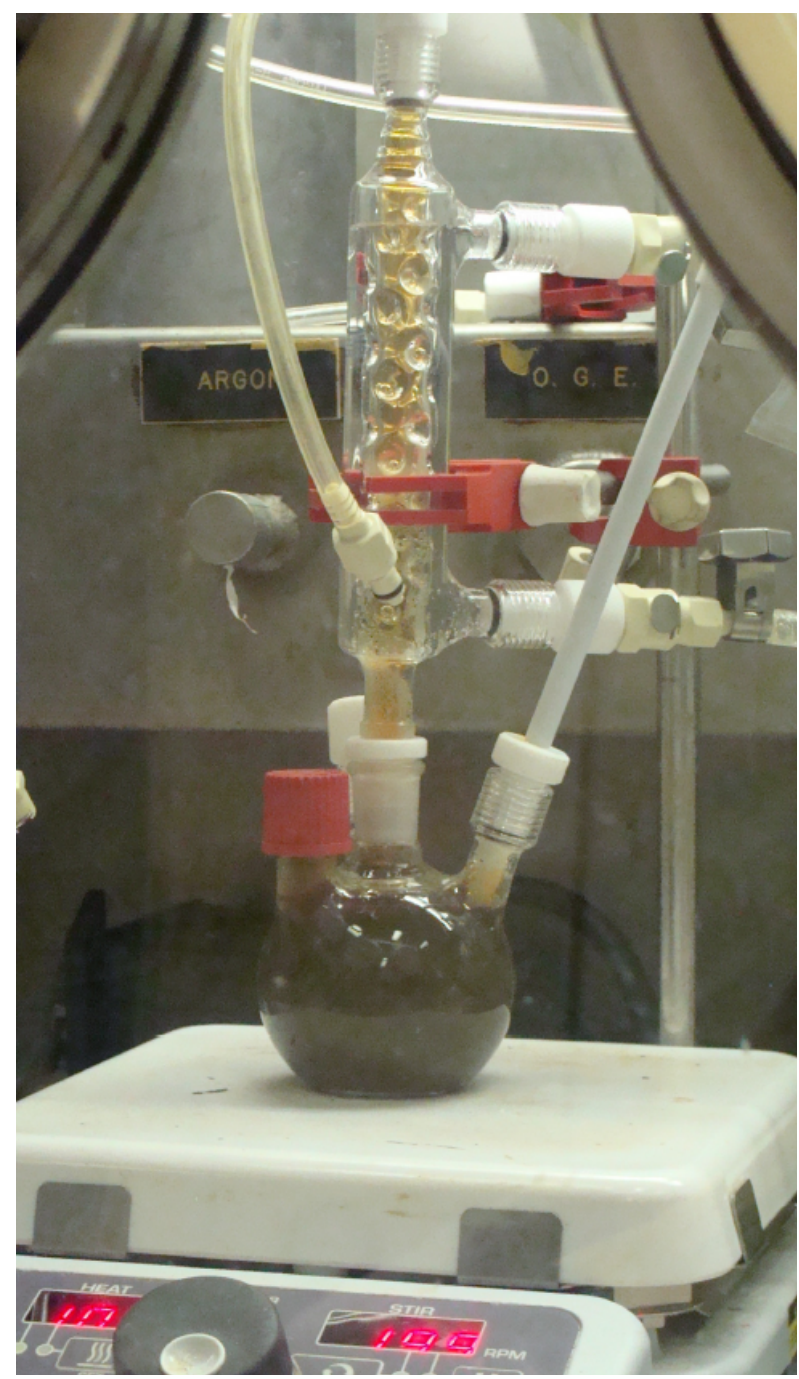
spectra indicated widely varying mixtures of $\mathrm{Np}^{4+}, \mathrm{Np}^{5+}$ and $\mathrm{Np}^{6+}$. Depending on the dissolution conditions (e.g. acid concentration and length of heating time), any one of the valence states of $\mathrm{Np}$ could dominate the mixture but all three were often present in the same solution. The data require further examination but initial review indicates that longer times at $12 \mathrm{M} \mathrm{HNO}_{3}$ may favor a high percentage of $\mathrm{Np}^{6+}$. In other tests, dissolution at $8 \mathrm{M}$ $\mathrm{HNO}_{3}$ resulted in a high percentage of $\mathrm{Np}^{4+}$. When gas samples were not removed from the system for analysis, the re-absorption of the majority of the offgas was observed as the apparatus cooled to ambient temperature. This gas volume loss is likely due to re-adsorption of the $\mathrm{NO} / \mathrm{NO}_{2}$ gases rather than leakage since the apparatus was tested repeatedly with argon and appeared capable of holding argon under 12 inches of water head pressure for 2.5 days with very little volume loss. A single instance of leakage from the thermocouple fitting was observed but in that case no gas could be collected at all. After that single observed leak issue, a leak check was incorporated into the experimental procedure as part of the apparatus flush with argon.

Figure 5. NpCo Vial 898 Dissolution Test. 
Overall Dissolution Tests: Table 3 contains a summary of the dissolution conditions, dissolution time and amount of solid residue for each of the $\mathrm{NpO}_{2}$ dissolution tests performed. Many of the initial experiments occurred at higher $\mathrm{HNO}_{3}$ and $\mathrm{KF}$ concentration than were found to be necessary. The amount of solids observed and measured will be discussed in more detail in a later section of the report. The $\mathrm{Np}$ value is calculated based on the values for $\mathrm{Np}$ assay provided for each material by HB-Line ${ }^{12}$.

Table 3. Np Dissolution Test Conditions ${ }^{c}$.

\begin{tabular}{|c|c|c|c|c|c|c|c|c|c|c|c|c|c|}
\hline Date & Test ID & Vial & $\begin{array}{c}\mathrm{HNO}_{3} \\
\mathrm{M} \\
\end{array}$ & $\begin{array}{l}\mathrm{KF} \\
\mathrm{M}\end{array}$ & $\begin{array}{l}\mathrm{Np} \\
\mathrm{g} / \mathrm{L}\end{array}$ & $\begin{array}{c}\mathrm{KF}^{\mathrm{d}} \\
\text { Delay }\end{array}$ & $\begin{array}{c}\mathrm{NpO}_{2} \\
\mathrm{~g} \\
\end{array}$ & $\begin{array}{c}\mathrm{Np} \\
\mathrm{g}\end{array}$ & $\begin{array}{l}\text { Vol } \\
\mathrm{mL} \\
\end{array}$ & $\begin{array}{l}\text { Time } \\
\min \\
\end{array}$ & $\begin{array}{c}\text { Solids } \\
\mathrm{g} \\
\end{array}$ & Solids & e \\
\hline 09/15/08 & $20014 \mathrm{MF}$ & 200 & 14.13 & 3.448 & 47.5 & & 0.54 & 0.48 & 10 & & 0.542 & $100 \%$ & Solids \\
\hline 09/30/08 & $19812 \mathrm{MF}$ & 198 & 11.62 & 0.099 & 18.8 & & 0.52 & 0.45 & 24 & 203 & 0.012 & $2.3 \%$ & \\
\hline $10 / 06 / 08$ & $19812 \mathrm{M}$ & 198 & 11.78 & 0.000 & 13.8 & & 0.51 & 0.44 & 32 & 197 & 0.014 & $2.8 \%$ & \\
\hline $10 / 07 / 08$ & $19712 \mathrm{M}$ & 197 & 12.27 & 0.000 & 14.2 & & soln & 0.46 & 32 & 190 & 0.007 & $0.0 \%$ & \\
\hline $10 / 09 / 08$ & $83812 \mathrm{M}$ & 838 & 11.78 & 0.070 & 19.2 & & 0.70 & 0.61 & 32 & 378 & 0.009 & $1.3 \%$ & \\
\hline $10 / 10 / 086: 45$ & $83812 \mathrm{MF}$ & 838 & 11.78 & 0.095 & 14.0 & & 0.51 & 0.45 & 32 & 136 & 0.001 & $0.2 \%$ & \\
\hline $10 / 11 / 086: 50$ & 838 12M2 & 838 & 11.78 & 0.000 & 14.4 & & 0.53 & 0.46 & 32 & 300 & 0.005 & $1.0 \%$ & \\
\hline 10/14/08 9:05 & $8982 \mathrm{M}$ & 838 & 1.96 & 0.086 & 14.9 & & 0.55 & 0.48 & 32 & 323 & 0.005 & $0.9 \%$ & \\
\hline 10/16/08 9:25 & $95112 \mathrm{M}$ & 951 & 11.78 & 0.077 & 14.6 & $\mathrm{Y}$ & 0.53 & 0.47 & 32 & 240 & 0.000 & $0.0 \%$ & \\
\hline $10 / 24 / 088: 55$ & $89812 \mathrm{M}$ & 898 & 11.78 & 0.080 & 14.6 & $\mathrm{Y}$ & 0.55 & 0.47 & 32 & 325 & 0.005 & $0.9 \%$ & \\
\hline 10/24/08 9:00 & 838 2M2 & 838 & 1.96 & 0.087 & 13.6 & $\mathrm{Y}$ & 0.50 & 0.44 & 32 & 220 & 0.006 & $1.2 \%$ & \\
\hline $10 / 28 / 0813: 26$ & 838 12M3 & 838 & 11.78 & 0.083 & 14.1 & & 0.51 & 0.45 & 32 & 64 & 0.004 & $0.8 \%$ & \\
\hline 10/29/08 9:35 & 838 12M4 & 838 & 11.78 & 0.086 & 53.2 & & 1.94 & 1.70 & 32 & 58 & 0.000 & $0.0 \%$ & \\
\hline 10/31/08 9:06 & 838 12M5 & 838 & 11.78 & 0.087 & 52.2 & $\mathrm{Y}$ & 1.90 & 1.67 & 32 & 104 & 0.006 & $0.0 \%$ & Leak \\
\hline 11/4/08 10:08 & 200 12M1 & 200 & 11.78 & 0.048 & 51.4 & $\mathrm{Y}$ & 1.88 & 1.65 & 32 & 143 & 0.009 & $0.5 \%$ & \\
\hline 11/5/08 8:43 & $20012 \mathrm{M} 2$ & 200 & 11.78 & 0.048 & 51.5 & & 1.88 & 1.65 & 32 & 47 & 0.003 & $0.2 \%$ & \\
\hline $11 / 5 / 08 \quad 13: 47$ & $20012 \mathrm{MF} 3$ & 200 & 13.74 & 0.028 & 52.1 & & 1.90 & 1.67 & 32 & 43 & 0.000 & $0.0 \%$ & \\
\hline $11 / 6 / 088: 33$ & 200 8MF4 & 200 & 8.09 & 0.025 & 50.2 & & 1.89 & 1.66 & 33 & 47 & 0.011 & $0.6 \%$ & \\
\hline 11/6/08 13:03 & $9518 \mathrm{MF} 2$ & 951 & 8.09 & 0.029 & 50.2 & & 1.89 & 1.66 & 33 & 59 & 0.032 & $1.7 \%$ & \\
\hline 11/7/08 8:35 & 838 8MF6 & 838 & 8.09 & 0.026 & 51.9 & & 1.95 & 1.71 & 33 & 60 & 0.000 & $0.0 \%$ & \\
\hline $11 / 7 / 08 \quad 12: 13$ & 200 8MF5 & 200 & 8.09 & 0.028 & 50.7 & & 1.91 & 1.67 & 33 & 60 & 0.000 & $0.0 \%$ & \\
\hline $11 / 12 / 08$ 12:45 & $2008 \mathrm{MF}^{g}$ & 200 & 8.56 & 0.023 & 15.4 & & 1.93 & 1.69 & 110 & 60 & 0.000 & $0.0 \%$ & \\
\hline 11/18/08 8:37 & $8958 \mathrm{MF}^{g}$ & 895 & 8.56 & 0.023 & 59.6 & & 8.91 & 6.56 & 110 & 155 & 1.321 & $14.8 \%$ & Solids \\
\hline 11/19/08 9:50 & $8988 \mathrm{MF}^{g}$ & 898 & 8.56 & 0.024 & 68.7 & & 9.19 & 7.56 & 110 & 150 & 0.069 & $0.8 \%$ & Solids \\
\hline 11/21/08 9:10 & 200 8MF7 & 200 & 8.09 & 0.000 & 13.3 & & 0.50 & 0.44 & 33 & 222 & 0.048 & $9.6 \%$ & Solids \\
\hline 12/1/08 10:05 & $2008 \mathrm{M} 8$ & 200 & 8.09 & 0.027 & 70.1 & & 2.64 & 2.31 & 33 & 110 & 0.005 & $0.2 \%$ & \\
\hline $12 / 2 / 088: 55$ & $838 \mathrm{MF}^{g}$ & 838 & 8.56 & 0.024 & 54.8 & & 6.87 & 6.03 & 110 & 127 & 0.000 & $0.0 \%$ & \\
\hline $12 / 2 / 08$ 13:42 & $8958 \mathrm{MF} 2^{f}$ & 895 & 8.09 & 0.027 & 0.0 & & 0.51 & & 33 & 105 & 0.000 & $0.0 \%$ & Solids \\
\hline 12/3/08 9:20 & $8958 \mathrm{MF} 2^{f}$ & 895 & 8.09 & 0.107 & 0.0 & & 0.51 & & 33 & 58 & 0.061 & $11.9 \%$ & Solids \\
\hline $12 / 3 / 0813: 13$ & $9468 \mathrm{MF}^{g}$ & 946 & 8.56 & 0.098 & 16.3 & & 2.10 & 1.79 & 110 & 67 & 0.000 & $0.0 \%$ & \\
\hline $12 / 4 / 087: 52$ & $9468 \mathrm{MF}^{g}$ & 946 & 8.56 & 0.024 & 61.9 & & 7.97 & 6.81 & 110 & 120 & 0.085 & $1.1 \%$ & Solids \\
\hline $\begin{array}{l}\text { Test } 200 \text { 14MF } \\
\text { KF Delay refers }\end{array}$ & $\begin{array}{l}\text { performed at } \\
\text { the addition of }\end{array}$ & $\begin{array}{l}{ }^{\circ} \mathrm{C} \text { an } \\
\mathrm{F} \text { to a }\end{array}$ & $\begin{array}{l}\text { Test } 198 \\
\text { ot dissol }\end{array}$ & $\begin{array}{l}\text { 12MF we } \\
\text { tion batc }\end{array}$ & $\begin{array}{l}\text { perforr } \\
\text { after th }\end{array}$ & $\begin{array}{l}\text { d at } 95^{\circ} \\
\text { nitial ba }\end{array}$ & $\begin{array}{l}\text { All ot } \\
\text { ch failed }\end{array}$ & $\begin{array}{l}\text { er tests } \\
\text { o comp }\end{array}$ & $\begin{array}{l}\text { were } p c \\
\text { etely d }\end{array}$ & $\begin{array}{l}\text { rformed } \\
\text { ssolve tl }\end{array}$ & $\begin{array}{l}100^{\circ} \mathrm{C} \\
\text { solids. }\end{array}$ & & \\
\hline
\end{tabular}


Gas Yield and Rates: Time, temperature and gas volume were measured for six dissolution experiments that span the range of the target materials for this campaign (i.e., NpCo source material, 898, HB-Line glovebox sweepings, 895 and 946, and SRNL thermogravimetric analysis samples, 200, 838 and 951). Figures 6 and 7 are plots of the temperature and gas generation results for these six experiments. Note that several tests used significantly less

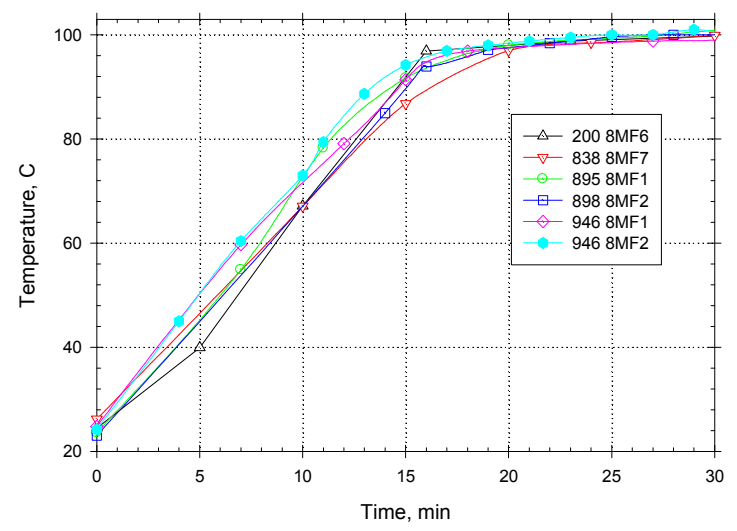

Figure 6. Temperature Profile over Time for $110 \mathrm{~mL}$ Dissolution Experiments.

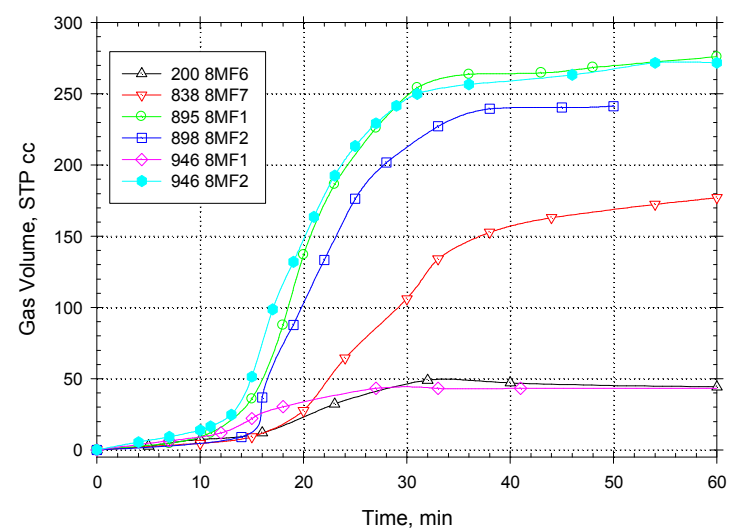

Figure 7. Gas Volume Evolved over Time.

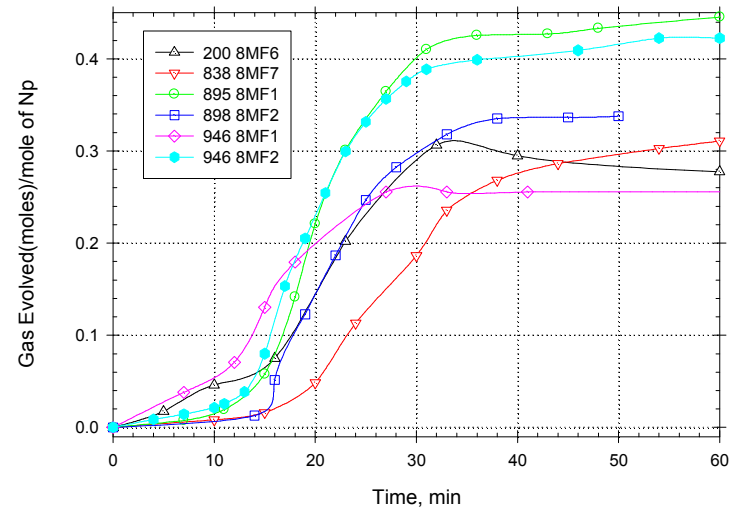

Figure 8. Gas Yield over Time mass of $\mathrm{Np}$ (see Table 3) and generated significantly less gas which limits the usefulness of that data. Correction of the data for the volume expansion of the headspace gas during heat-up was not performed due to insufficient volumetemperature data. This correction should be relatively small when the total gas generated is $>200 \mathrm{cc}$. The lack of this correction is conservative in that it biases the gas generation results high.

If all the $\mathrm{Np}$ were dissolved and oxidized to $\mathrm{Np}^{6+}$, a maximum of two moles of $\mathrm{NO}_{2}$ gas could be evolved for each mole of $\mathrm{Np}$. If $\mathrm{NO}$ were the only gas product, a maximum 0.67 moles of NO could be evolved. As will be discussed later a mixture of nitrogen oxide gases (including $\mathrm{N}_{2} \mathrm{O}$ ) was observed in all tests. Figure 8 shows the molar gas yield for the same six dissolution tests. The ultimate yield of gas ranged from 0.25 to 0.42 moles of gas per mole of $\mathrm{NpO}_{2}$ dissolved.

The off-gas processing concern during dissolution is the potential to produce more gas than the vessel ventilation system is designed to handle. This concern could be either for flammable gas dilution or pressurization of the vessel. This study sought to measure not only the total amount of gas evolved but also the rate at which that gas evolves over time during processing. Figures 9 and 10 are plots of rate data over time for the six dissolution experiments in units of moles per mole of $\mathrm{Np}$ and units of scfm per kilogram of bulk oxide. Use of the latter units avoids the composition uncertainty of the residue as it is scaled to the total mass of material charged to the 


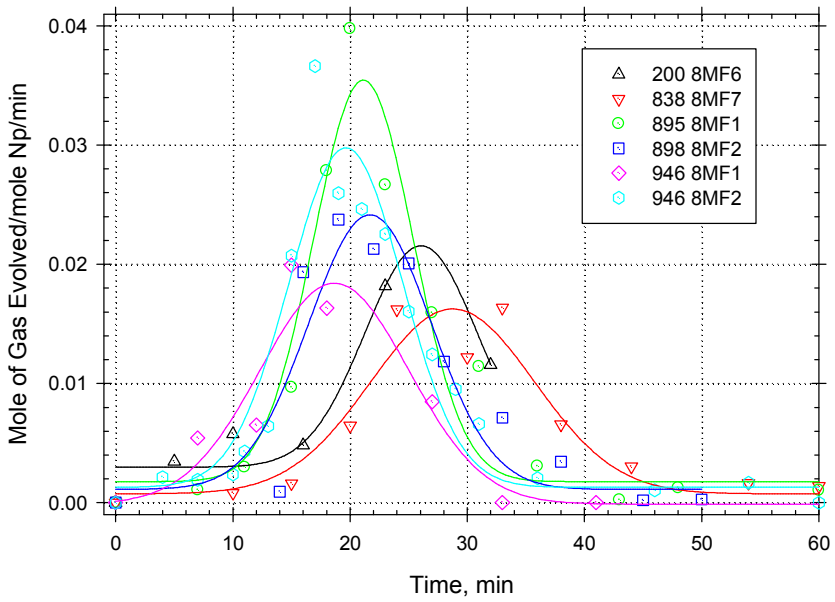

Figure 9. Molar Gas Yield Rate over Time.

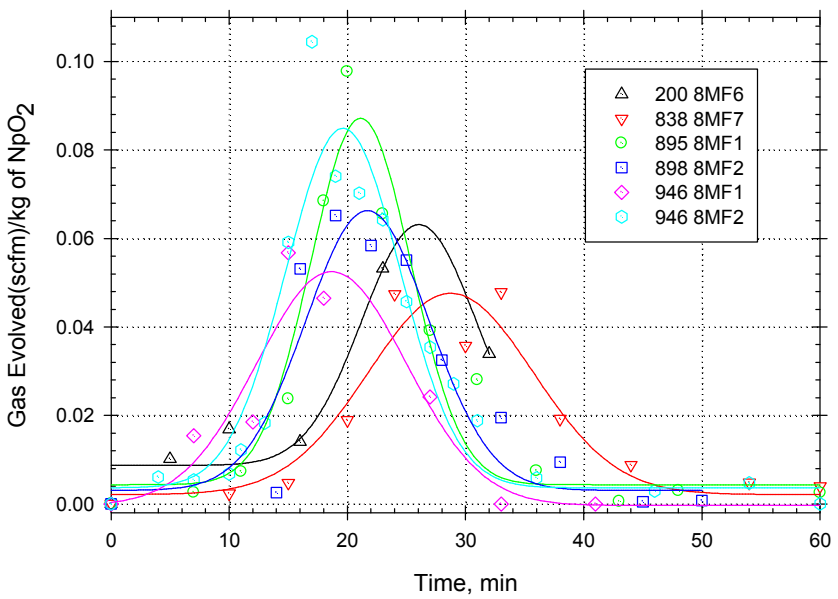

Figure 10. Rate of Gas Evolution per kg of Bulk Oxide over Time. dissolver. Smooth curves were not readily fit through the data but a 4-parameter Gaussian Peak fit using SigmaPlot 10.0 software produced the curves shown.

Peak off-gas rates of $\sim 0.104 \mathrm{scfm} / \mathrm{kg}$ of bulk Np material $\quad(0.036$ moles $/$ mole of $\mathrm{NpO}_{2} / \mathrm{min}$ ) were observed. This off-gas rate compares favorably with a $20 \mathrm{scfm}$ purge rate for the HB-Line dissolver. The generation values based on moles of $\mathrm{Np}$ dissolved are expected to increase by $\sim 10 \%$ when corrected with a measured $\mathrm{Np}$ assay value for the actual samples tested.

Tables 7 through 12 in the appendix contain the gas evolution data for Figures 6 through 10.

Gas Analyses: Gas compositional analysis was initially not part of the scope of this work but was incorporated as the work proceeded due to the amount of gas produced. Sampling was performed as described in the gas collection test section and analyzed per the standard GC

method. This method was recognized to be limited in that it does not attempt to quantify $\mathrm{NO}_{2}$ which is a significant component of the off-gas from these dissolution experiments. Based on the calculated internal volume of the apparatus of $84.9 \mathrm{cc}$, an argon concentration

Table 4. Gas Analysis Results for Dissolution of $\mathrm{NpO}_{2}$ Samples ${ }^{a}$.

\begin{tabular}{lcccccccc}
\hline & LIMS ID & $\mathrm{H}_{2}$ & $\mathrm{O}_{2}$ & $\mathrm{~N}_{2}$ & $\mathrm{NO}$ & $\mathrm{N}_{2} \mathrm{O}$ & $\mathrm{CO}$ & $\mathrm{NO}_{2}$ \\
\hline Vial \#898 NpCo Gas\#1 & $3-255203$ & $<0.13$ & $<0.13$ & $<0.13$ & 64 & 14.1 & $<0.13$ & 21 \\
Vial \#898 NpCo Gas\#2 & $3-255204$ & $<0.13$ & $<0.13$ & $<0.13$ & 71 & 7.8 & $<0.13$ & 21 \\
\hline Vial \#895 Part I Sweepings Gas\#1 & $3-255205$ & $<0.13$ & $<0.13$ & $<0.13$ & 50 & 3.0 & $<0.13$ & 46 \\
Vial \#895 Part I Sweepings Gas\#2 & $3-255206$ & $<0.13$ & $<0.13$ & $<0.13$ & 73 & 1.6 & $<0.13$ & 25 \\
\hline Vial \#946 Part II Sweepings Gas\#1 & $3-255746$ & $<0.13$ & $<0.13$ & $<0.13$ & 28 & 2.6 & $<0.13$ & 69 \\
Vial \#946 Part II Sweepings Gas\#2 & $3-255747$ & $<0.13$ & $<0.13$ & $<0.13$ & 30 & 5.9 & $<0.13$ & 63 \\
\hline Vial \#838 1000 ${ }^{\circ} \mathrm{C} \mathrm{NpO}_{2}$ Gas\#1 & $3-255744$ & $<0.14$ & $<0.14$ & $<0.14$ & 35 & 7.2 & $<0.14$ & 57 \\
Vial \#838 1000 ${ }^{\circ} \mathrm{C} \mathrm{NpO}_{2}$ Gas\#2 & $3-255745$ & $<0.14$ & $<0.14$ & $<0.14$ & 66 & 3.2 & $<0.14$ & 30 \\
\hline
\end{tabular}

${ }^{a}$ Units are volume percent on an Ar-free basis. 
was calculated for each experiment and a $\mathrm{NO}_{2}$ concentration was estimated assuming that argon and $\mathrm{NO}_{2}$ were the only un-quantified gases present. Gas samples were analyzed from dissolution experiments using the following materials: NpCo source oxide, $1000{ }^{\circ} \mathrm{C} \mathrm{Calcined}$ TGA $\mathrm{NpO}_{2}$, and $\mathrm{Np}$ sweeping samples from the Part I and Part II campaigns. In each case duplicate gas samples were taken simultaneously. In the Part I Sweepings experiment (Vial 895), the gas samples were taken after $141 \mathrm{~min}$, but for the other three materials, gas samples were taken at $\sim 1$ hour. As shown in Table 4 , none of these experiments showed any indication that hydrogen was produced during dissolution of any of these $\mathrm{NpO}_{2}$ samples. There was also no indication that the integrity of the sample was affected by any in-leakage of air. The duplicate samples did not show good agreement on the nitrogen oxides. The NO result appears to vary widely between duplicate samples. With the variation between duplicate samples, it is difficult to determine if there is any significance between differences in the NO yield between the different material types. Note that the results as shown in Table 4 are corrected to an Ar-free basis to reflect the composition of the gas evolved. (For the laboratory apparatus, the argon dilution amounted to $20-26 \%$ of the total off-gas collected.)

Residual Solids: Table 3 contains results of the amount of solids found on air-dried filter papers from the filtration of the dissolver solution at the end of each test. In six experiments some visible solids were observed. Three of those experiments involved the solids found in the Part I Sweepings material. (Two out of those three were additional attempts to completely dissolve the silica residue from the first experiment.) The material from Part I Sweepings dissolution (895 8MF1) was dried overnight and contained $\sim 15 \%$ of the initial mass of material used. However, after sampling for SEM and XRD analyses (usually $<0.1 \mathrm{~g}$ bulk) and air drying for two weeks, the remaining sample had lost significant weight (1.321g dropped to $0.513 \mathrm{~g}$ or only $5.7 \%$ of the original mass charged). The residue from the Part I Sweeping dissolution had a significant thickness (compared to that from the other experiments) and apparently took much longer to dry than other samples. Rather than the $15 \mathrm{wt} \%$ initially measured, it was likely no more than $\sim 8 \mathrm{wt} \%$ residual solids (including estimated mass of samples). The dried residue from this initial test (895 8MF1) was later used as feed material for a separate dissolution test with fresh solution (895 8MF2). After 105 min of heating without visible progress, the solution was allowed to cool overnight, the KF concentration was increased to $0.1 \mathrm{M}$ and the solution was again heated for another $58 \mathrm{~min}$. Although the amount of solids did decrease during this treatment, the final solution remained nearly colorless indicating that an insignificant amount of $\mathrm{Np}$ leached from the solids. This lack of solution color is consistent with the SEM observations that the residual solids from Part I Sweepings dissolution did not contain significant Np solids.

The only other experiment where significant solids were observed was a dissolution attempt

Table 5. XRD and SEM Characterization of Np Dissolution Residues.

\begin{tabular}{c}
\hline $895 \mathrm{~Np}$ Sweepings I: mostly $\mathrm{Si}$, lesser amounts of $\mathrm{Fe}-\mathrm{Cr}-\mathrm{Ni}, \mathrm{Pu}$; some small Np particles \\
Non-crystalline $\mathrm{Si}$ not identified by $\mathrm{XRD}$ \\
\hline $898 \mathrm{NpCo}$ : largest particles are $\mathrm{Al}-\mathrm{Si}$ round beads; lesser amounts of $\mathrm{Pu}, \mathrm{Np}$, and $\mathrm{Sn}$ \\
XRD indicated Boehmite (AlOOH) \\
\hline $946 \mathrm{~Np}$ Sweepings II: mostly $\mathrm{Si}$, lesser amounts of $\mathrm{Fe}-\mathrm{Cr}-\mathrm{Ni}$, few large Pu particles, some small Np particles \\
XRD identified Quartz, talc, $\mathrm{NpO}_{2}$ with a large non-crystalline signal as in 895 sample \\
\hline
\end{tabular}


without KF to prepare a solid sample of the yellow green residue to confirm the X-ray pattern of the solids. With $0.025 \mathrm{M} \mathrm{KF}$ present, only the Part I Sweepings sample left significantly more than $1 \mathrm{wt} \%$ solid residue after heating for 1 to 2.5 hours. The Part I Sweepings sample was initially heated for 2.6 hours and although there was significant residue, that residue proved to be mostly composed of silica, stainless steel and other non-actinide compounds (Table 5). Further heating of that residue for 3 additional hours with fresh solution and additional fluoride reduced the residue mass but did not appear to leach significant $\mathrm{Np}$ from the residue. Because a significant fraction of the $\mathrm{Np}$ materials to be processed are from the sweepings category, a dissolution time of no less than 3 hours is recommended for plant processing. Additional time beyond 3 hours should reduce the amount of total residues left from the sweepings, but the $\mathrm{NpO}_{2}$ is expected to dissolve during the initial 1 to 2.5 hours at temperature.

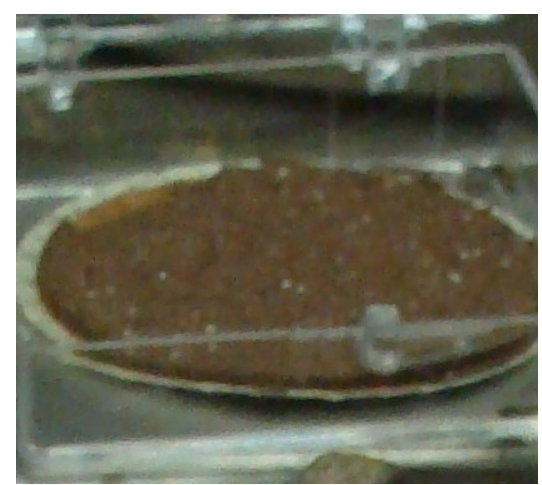

Figure 11. Solids from Vial 895 (Sweepings I) Dissolution.

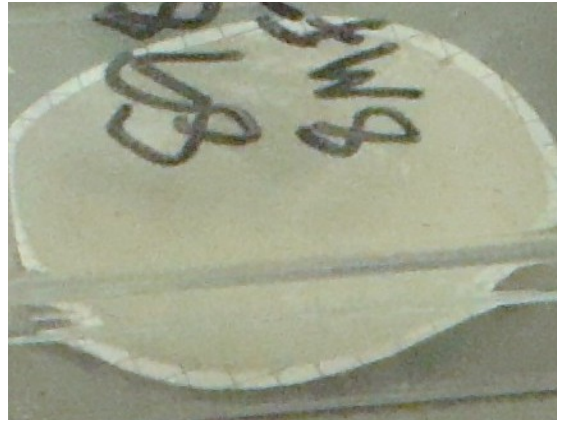

Figure 13. Solids from Vial 898 (NpCo) Dissolution.

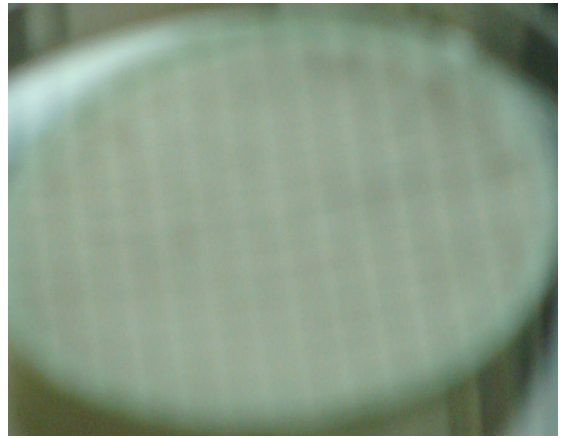

Figure 15. Solids from Vial 838 $\left(1000^{\circ} \mathrm{C}\right.$ TGA $\left.\mathrm{NpO}_{2}\right)$ Dissolution.

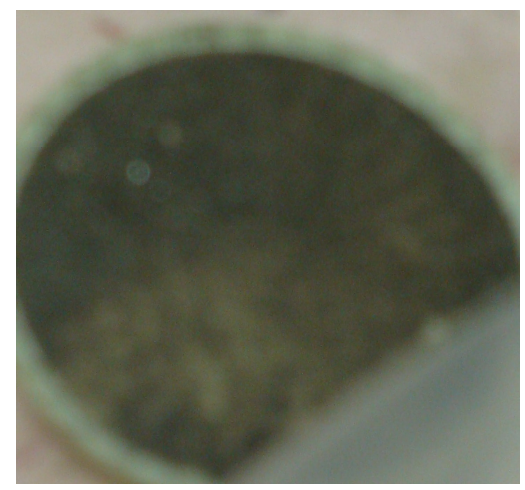

Figure 12. Solids from Vial 946 8MF2 (Sweepings II) Dissolution.

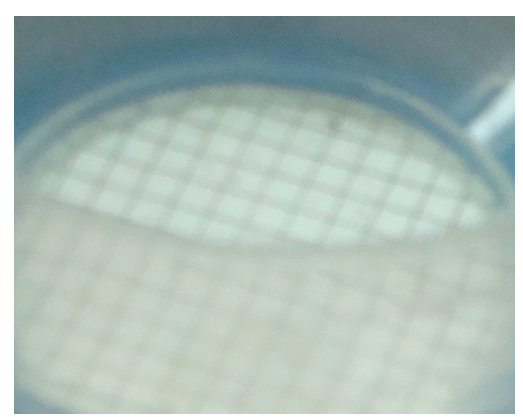

Figure 14. Solids from Vial 200 $\left(650^{\circ} \mathrm{C} \mathrm{NpO}_{2}\right)$ Dissolution.

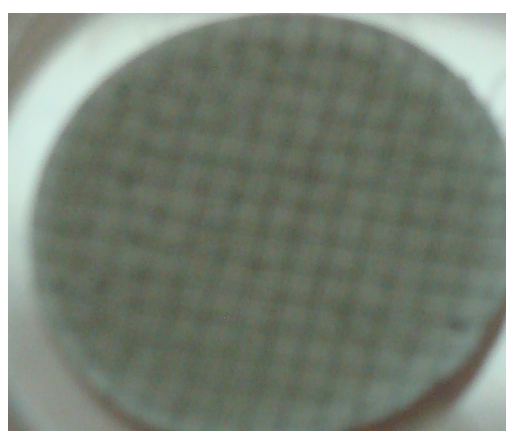

Figure 16. Solids from Vial 946 8MF1 Dissolution
Photos of the Part I and II Sweepings residues after dissolution and filtration are included as Figures 11 and 12. Although the photo is blurred, it can be seen that the Part II Sweepings resulted in appreciably less residual solids after dissolution. The NpCo material resulted in less residual solids than the Part II Sweepings. None of the other materials tested generated significant residue. Comparable photos of $\mathrm{NpCo}, 1000{ }^{\circ} \mathrm{C}$ TGA, $650{ }^{\circ} \mathrm{C} \mathrm{NpO}$, and the initial Part II Sweepings residues (946 $8 \mathrm{MF} 1)$ are included as Figures 13, 14, 15, and 16. Table 5 provides a description of the dissolution residues as identified by XRD/SEM analyses. 
Aluminum Nitrate Solubility: The initial flowsheet proposed for dissolution of these materials was12 $\mathrm{M} \mathrm{HNO}_{3}$ and 0.1 to $0.3 \mathrm{M} \mathrm{KF}$ based on prior internal reports ${ }^{7,8}$. At those levels of nitrate and fluoride, the complexation of fluoride at a 3:1 molar ratio would be expected to exceed the solubility of aluminum nitrate unless significant dilution of the nitrate was performed. Aluminum nitrate solubility in $12 \mathrm{M} \mathrm{HNO}_{3}$ is reported at $\sim 0.12 \mathrm{M}$ at $20{ }^{\circ} \mathrm{C}$ whereas at $8 \mathrm{M} \mathrm{HNO}_{3}$, the solubility is reported at $\sim 0.67 \mathrm{M}$ at $20{ }^{\circ} \mathrm{C}^{13}$. Dissolution in $12 \mathrm{M} \mathrm{HNO}_{3}$ requires attention to the amount of dilution performed prior to the addition of aluminum nitrate solution (usually in the form of $34 \mathrm{wt} \%$ aluminum nitrate). When dissolution is performed in $8 \mathrm{M} \mathrm{HNO}_{3}$ with $<0.1 \mathrm{M} \mathrm{KF}$, aluminum nitrate solubility should not be a concern.

Table 6. Aluminum Nitrate Solubility Test.

\begin{tabular}{lccc}
\hline & $\begin{array}{c}\text { Np, } \\
\text { g/L }\end{array}$ & $\begin{array}{c}\text { HNO3, } \\
\text { M }\end{array}$ & $\begin{array}{c}\text { KF, } \\
\text { M }\end{array}$ \\
\hline 895 8MF2 w ANN & 0.0 & 7.13 & 0.095 \\
946 8MF2 w ANN & 61.5 & 8.32 & 0.023 \\
946 8MF1 w ANN & 14.2 & 7.66 & 0.087 \\
895 8MF1 w ANN & 68.4 & 8.32 & 0.023 \\
898 8MF2 w ANN & 66.8 & 8.32 & 0.023 \\
\hline
\end{tabular}

Tests were performed on the five final dissolver samples listed in Table 6 to confirm that these solutions show the expected solubility behavior. In each case a minimum of 3 moles of aluminum nitrate (34 wt \% solution in water) were added per mole of fluoride in the solution. The concentrations shown in Table 6 reflect the dilution from the water from the use of a $34 \mathrm{wt} \%$ aluminum nitrate reagent.

No solids were observed to form in any of the five dissolver solution samples within two weeks of adjustment with $34 \mathrm{wt} \%$ aluminum nitrate.

\section{Recommendations:}

1) Dissolve $\mathrm{NpO}_{2}$ materials in an $8 \mathrm{M} \mathrm{HNO}_{3} / 0.025 \mathrm{M} \mathrm{KF}$ solution at $100{ }^{\circ} \mathrm{C}$ for no less than 3 hours. Np loading of 50 to $70 \mathrm{~g} \mathrm{~Np} / \mathrm{L}$ was demonstrated but silica and other non-Np impurities did not completely dissolve in the time allotted. A loading of $50 \mathrm{~g} \mathrm{~Np} / \mathrm{L}$ is recommended (equivalent to $750 \mathrm{~g} \mathrm{~Np}$ dissolved into $15 \mathrm{~L}$ of acid solution) as this loading should be sufficient to process the projected inventories in a reasonable number of batches.

2) Be prepared for concentrations of harder-to-dissolve impurities (i.e., silica, iron-nickelchromium, and boehmite) in the range of 1 to $8 \mathrm{wt} \%$ of the bulk material charged. Longer dissolution cycles and higher levels of fluoride will tend to reduce the amount of residual solids produced but are not expected to eliminate them entirely.

3) Be prepared for an off-gas rate as great as to $0.11 \mathrm{scfm} / \mathrm{kg}$ of bulk material. The off-gas will be composed of $\mathrm{NO}, \mathrm{NO}_{2}$ and $\mathrm{N}_{2} \mathrm{O}$. No $\mathrm{H}_{2}$ off-gas is expected. Since HB-Line operates with an air purge, the $\mathrm{NO}$ produced will be rapidly oxidized to $\mathrm{NO}_{2}$ which will reduce the actual off-gas rate observed in the field. 


\section{Conclusions:}

A dissolution flowsheet for processing various $\mathrm{NpO}_{2}$ materials has been developed and demonstrated by SRNL with samples of the materials from HB-Line. This flowsheet should allow for the disposition of these types of materials in HB-Line with only limited amounts of non-Np solid residues remaining. The off-gas from this process will be composed of NO, $\mathrm{NO}_{2}$ and $\mathrm{N}_{2} \mathrm{O}$ gases but no $\mathrm{H}_{2}$ was observed in the laboratory.

\section{Acknowledgements:}

The author wishes to acknowledge Wanda Matthews (SRNL-ALP) for her dedicated work in performing the experimental work. The author also would like to acknowledge Steve Crump (SRNL-AD) for his contribution in performing the gas analyses as well as Dave Missimer, Art Jurgensen, Mike Summer and Jack Durden (SRNL-AD) for performing the various rush analyses on the undissolved solids in order to get this work completed in a timely manner. Gary Dobos and Curt Sexton (SRNL-AD) fabricated the specialized glassware used for this work.

\section{References:}

${ }^{1}$ B. L. Sims, Jr. to R. S. Beck, "Re: F/H and HBL NpCo disposition follow-up meeting----meeting minutes and action item," May 16, 2007

${ }^{2}$ Customer Sample Report, Analytical Laboratories, Sample ID; 200370763, Lot ID: Vial 170: Np Source from HBL, NM\#82-513, November 23, 2004

3 Customer Sample Report, Analytical Laboratories, Sample ID: 200370799 Lot ID: Vial 188, Np Source, NM\#82-514, November 23, 2004

${ }^{4}$ A. R. Jurgensen, "Results of XRD Analysis of AD samples 3002226921 \& 30002226911 ", electronic mailed results on the XRD Analysis of Np Source Material submitted by B. Hill, September 13, 2005

${ }^{5}$ E. A. Kyser, "Task Technical and Quality Assurance Plan: - Flowsheet for NpCo and Np Oxide Scrap Dissolution in HB-Line", SRNL-RP-2008-01115, Rev. 0, November 4, 2008

${ }^{6}$ R. A. Pierce, N. J. Bridges, M. G. Bronikowski, “ Basis for Hydrogen Gas Testing during Flowsheet Development Studies”, WSRC-STI-2008-00267, Washington Savannah River Co, June 2008

7 W. L. Poe, "Dissolution of $\mathrm{NpO}_{2}$ in H-Area B-Line," Test Authorization \#2-528, DPSOX 6009, September 15,1964

${ }^{8}$ R. C. Marozas, "Dissolution of $\mathrm{NpO}_{2}$ in H-Area B-Line," Test Conclusion \#2-528, DPSOX 6352, November 23, 1965

9 J. L. Bodkin, “Dissolving Np Oxide in HB-Line Phase 1,” NMMD-HTS-2008-3028, October 13, 2008

${ }^{10}$ J. L. Bodkin, Response to comments on "TTR for Np" electronic mail, October 14, 2008

${ }^{11}$ E. A. Kyser, "Np Dissolution, Ion Exchange, Solvent Extraction, Precipitation Experimentation", SRNLL3000-2008-00013, Rev. 0, October 29, 2008

12 J. L. Bodkin, B. L. Sims, “Off spec Neptunium Oxide Sampling for Flowsheet Development”, SRNS-N00002008-00003, draft, January 7, 2008

13 “ 200 Area Process Guidebook”, DPSOP 250, E. I. du Pont de Nemours and Co, Aiken, SC, November, 1977 
SRNL-STI-2008-00523, Rev 0

Appendix 
Table 7. Gas Results for Pure $\mathrm{NpO}_{2}$ Material.

\begin{tabular}{|c|c|c|c|c|c|c|}
\hline \multicolumn{7}{|c|}{$2008 \mathrm{MF} 6, \mathrm{NpO}_{2} 650^{\circ} \mathrm{C}, 1.927 \mathrm{~g}$ oxide, $22^{\circ} \mathrm{C}$} \\
\hline $\begin{array}{l}\text { Time, } \\
\min \\
\end{array}$ & $\mathrm{V}$, & $\begin{array}{l}\mathrm{T}, \\
{ }^{\circ} \mathrm{C} \\
\end{array}$ & $\begin{array}{l}\mathrm{V}^{*}, \\
\mathrm{cc}\end{array}$ & $\begin{array}{c}\text { Gas Yield, } \\
\text { mol gas/ } \\
\text { mol Np }\end{array}$ & $\begin{array}{c}\text { Gas R } \\
\text { mol gas } \\
\text { mol Np/min }\end{array}$ & $\begin{array}{l}\text { scfm/ } \\
\text { kg oxide }\end{array}$ \\
\hline 0 & 32 & 24.5 & 0.0 & 0.000 & & \\
\hline 5 & 35 & 39.9 & 2.8 & 0.017 & 0.003 & 0.010 \\
\hline 10 & 40 & 67.1 & 7.4 & 0.046 & 0.006 & 0.017 \\
\hline 16 & 45 & 96.9 & 12.0 & 0.075 & 0.005 & 0.014 \\
\hline 23 & 67 & 98.8 & 32.3 & 0.202 & 0.018 & 0.053 \\
\hline 32 & 85 & 100 & 48.9 & 0.306 & 0.012 & 0.034 \\
\hline 40 & 83 & 100 & 47.1 & 0.295 & & \\
\hline 60 & 80 & 100 & 44.3 & 0.277 & & \\
\hline 80 & 50 & 79.4 & 16.6 & 0.104 & Apparatus co & \\
\hline
\end{tabular}

Table 8. Gas Results for Pure $\mathrm{NpO}_{2}$ Material.

\begin{tabular}{|c|c|c|c|c|c|c|}
\hline \multicolumn{7}{|c|}{838 8MF7, $\mathrm{NpO}_{2} 1000^{\circ} \mathrm{C}, 6.871 \mathrm{~g}$ oxide, $23.7^{\circ} \mathrm{C}$} \\
\hline $\min$ & $\mathrm{V}$ & $\mathrm{T}$, & $\mathrm{V}^{*}$ & $\begin{array}{c}\text { Gas Yield, } \\
\text { mol gas/ } \\
\text { mol Np }\end{array}$ & $\begin{array}{c}\text { Gas } \\
\text { mol gas } \\
\text { mol Np/min }\end{array}$ & $\begin{array}{l}\text { scfm/ } \\
\text { kg oxide }\end{array}$ \\
\hline 0 & 50 & 26.2 & 0.0 & 0.000 & & \\
\hline 10 & 55 & 67.1 & 4.6 & 0.008 & 0.001 & 0.002 \\
\hline 15 & 60 & 86.8 & 9.2 & 0.016 & 0.002 & 0.005 \\
\hline 20 & 80 & 97 & 27.6 & 0.048 & 0.006 & 0.019 \\
\hline 24 & 120 & 98.5 & 64.5 & 0.113 & 0.016 & 0.047 \\
\hline 30 & 165 & 99.9 & 106.2 & 0.186 & 0.012 & 0.036 \\
\hline 33 & 195 & 100 & 134.1 & 0.235 & 0.016 & 0.048 \\
\hline 38 & 215 & 100 & 152.7 & 0.268 & 0.007 & 0.019 \\
\hline 44 & 226 & 99.9 & 163.0 & 0.286 & 0.003 & 0.009 \\
\hline 54 & 236 & 100 & 172.4 & 0.303 & 0.002 & 0.005 \\
\hline 60 & 241 & 100 & 177.1 & 0.311 & 0.001 & 0.004 \\
\hline 62 & 170 & 100 & 110.8 & \multirow{3}{*}{\multicolumn{3}{|c|}{ Gas Samples Pulled }} \\
\hline 163 & 168 & 100 & 109.0 & & & \\
\hline 167 & 168 & 100 & 109.0 & & & \\
\hline
\end{tabular}


Table 9. Gas Results for NpCo Source Material.

\begin{tabular}{|c|c|c|c|c|c|c|}
\hline \multicolumn{7}{|c|}{898 8MF2, NpCo , $9.193 \mathrm{~g}$ oxide, $23{ }^{\circ} \mathrm{C}$} \\
\hline \multirow{2}{*}{$\begin{array}{l}\text { Time, } \\
\text { min }\end{array}$} & \multirow{2}{*}{$\begin{array}{l}\mathrm{V}, \\
\mathrm{cc} \\
\end{array}$} & \multirow{2}{*}{$\begin{array}{l}\mathrm{T}, \\
{ }^{\circ} \mathrm{C} \\
\end{array}$} & \multirow{2}{*}{$\begin{array}{l}\mathrm{V}^{*}, \\
\mathrm{cc} \\
\end{array}$} & \multirow{2}{*}{$\begin{array}{c}\text { Gas Yield, } \\
\text { mol gas/ } \\
\text { mol Np }\end{array}$} & \multicolumn{2}{|c|}{ Gas Rate, } \\
\hline & & & & & $\begin{array}{c}\text { mol gas } \\
\mathrm{mol} \mathrm{Np} / \mathrm{min}\end{array}$ & $\begin{array}{c}\text { scfm/ } \\
\text { kg oxide }\end{array}$ \\
\hline 0 & 40 & 23 & 0.0 & 0.000 & & \\
\hline 14 & 50 & 85 & 9.2 & 0.012 & 0.001 & 0.003 \\
\hline 16 & 80 & 939 & 36.8 & 0.050 & 0.019 & 0.053 \\
\hline 19 & 135 & 97.1 & 87.7 & 0.119 & 0.023 & 0.065 \\
\hline 22 & 184 & 98.4 & 133.3 & 0.181 & 0.021 & 0.058 \\
\hline 25 & 230 & 99.6 & 176.4 & 0.239 & 0.019 & 0.055 \\
\hline 28 & 257 & 100 & 201.7 & 0.274 & 0.011 & 0.032 \\
\hline 33 & 284 & 100 & 227.1 & 0.308 & 0.007 & 0.020 \\
\hline 38 & 297 & 100 & 239.4 & 0.325 & 0.003 & 0.009 \\
\hline 45 & 298 & 99.7 & 240.4 & 0.326 & 0.000 & 0.001 \\
\hline 50 & 299 & 100 & 241.3 & 0.327 & 0.000 & 0.001 \\
\hline 58 & 293 & 100 & 235.6 & & & \\
\hline 64 & 200 & 100 & 148.3 & \multicolumn{3}{|c|}{ Gas Samples Pulled } \\
\hline 145 & 94 & 100 & 49.8 & & & \\
\hline
\end{tabular}

Table 10. Gas Results for Np Sweepings Material.

\begin{tabular}{|c|c|c|c|c|c|c|}
\hline \multicolumn{7}{|c|}{$8958 \mathrm{MF} 1$, Sweepings, $8.908 \mathrm{~g}$ oxide, $23.4^{\circ} \mathrm{C}$} \\
\hline $\begin{array}{l}\text { Time, } \\
\text { min }\end{array}$ & $\mathrm{V}$ & ${ }^{\circ} \mathrm{C}$ & $\begin{array}{l}\mathrm{V}^{*}, \\
\mathrm{cc}\end{array}$ & $\begin{array}{c}\text { Gas Yield, } \\
\text { mol gas/ } \\
\text { mol Np }\end{array}$ & $\begin{array}{c}\text { Gas } \\
\text { mol gas } \\
\text { mol Np/min }\end{array}$ & $\begin{array}{l}\text { scfm/ } \\
\text { kg oxide }\end{array}$ \\
\hline 0 & 42 & 23.6 & 0.0 & 0.000 & & \\
\hline 7 & 47 & 54.9 & 4.6 & 0.008 & 0.001 & 0.003 \\
\hline 11 & 55 & 78.3 & 11.9 & 0.021 & 0.003 & 0.007 \\
\hline 15 & 81 & 91.7 & 35.9 & 0.063 & 0.010 & 0.024 \\
\hline 18 & 137 & 96.4 & 87.6 & 0.153 & 0.030 & 0.068 \\
\hline 20 & 190 & 98 & 136.9 & 0.239 & 0.043 & 0.098 \\
\hline 23 & 243 & 99 & 186.5 & 0.326 & 0.029 & 0.066 \\
\hline 27 & 285 & 99.8 & 225.9 & 0.395 & 0.017 & 0.039 \\
\hline 31 & 315 & 101 & 254.2 & 0.444 & 0.012 & 0.028 \\
\hline 36 & 325 & 100 & 263.7 & 0.461 & 0.003 & 0.008 \\
\hline 43 & 326 & 99.5 & 264.7 & 0.462 & 0.000 & 0.001 \\
\hline 48 & 330 & 99.9 & 268.4 & 0.469 & 0.001 & 0.003 \\
\hline 60 & 338 & 100 & 276.0 & 0.482 & 0.001 & 0.003 \\
\hline 141 & 257 & 100 & 199.6 & Gas Samples & lled & \\
\hline 155 & 256 & 100 & 198.7 & & & \\
\hline 262 & 114 & 33 & 66.3 & & & \\
\hline 280 & 115 & 30.5 & 67.2 & & & \\
\hline
\end{tabular}


Table 11. Gas Results for Np Sweepings Material.

\begin{tabular}{|c|c|c|c|c|c|c|}
\hline \multicolumn{7}{|c|}{$9468 \mathrm{MF} 1$, Sweepings $2,2.095 \mathrm{~g}$ oxide, $23.7^{\circ} \mathrm{C}$} \\
\hline $\begin{array}{l}\text { Time, } \\
\text { min }\end{array}$ & $\mathrm{V}$, & $\begin{array}{l}\mathrm{T}, \\
{ }^{\circ} \mathrm{C} \\
\end{array}$ & $\begin{array}{l}\mathrm{V}^{*}, \\
\mathrm{cc}\end{array}$ & $\begin{array}{c}\text { Gas Yield, } \\
\text { mol gas/ } \\
\text { mol Np }\end{array}$ & $\begin{array}{c}\text { Gas } \mathrm{R} \\
\text { mol gas } \\
\text { mol Np/min }\end{array}$ & scfm/ \\
\hline 0 & 43 & 24.8 & 0.0 & 0.000 & & \\
\hline 7 & 50 & 59.7 & 6.4 & 0.037 & 0.005 & 0.015 \\
\hline 12 & 56 & 79.1 & 11.9 & 0.070 & 0.006 & 0.019 \\
\hline 15 & 67 & 91.4 & 22.0 & 0.128 & 0.020 & 0.057 \\
\hline 18 & 76 & 96.9 & 30.3 & 0.177 & 0.016 & 0.047 \\
\hline 27 & 90 & 98.8 & 43.2 & 0.252 & 0.008 & 0.024 \\
\hline 33 & 90 & 99 & 43.2 & 0.252 & 0.000 & 0.000 \\
\hline 41 & 90 & 99 & 43.2 & 0.252 & 0.000 & 0.000 \\
\hline 67 & 90 & 99 & 43.2 & 0.252 & 0.000 & 0.000 \\
\hline
\end{tabular}

Table 12. Gas Results for Np Sweepings Material.

\begin{tabular}{|c|c|c|c|c|c|c|}
\hline \multicolumn{7}{|c|}{946 8MF2, Sweepings $2,7.971 \mathrm{~g}$ oxide, $23.8^{\circ} \mathrm{C}$} \\
\hline $\begin{array}{l}\text { Time, } \\
\text { min }\end{array}$ & $\mathrm{V}$ & ${ }^{\circ} \mathrm{C}$ & $\mathrm{V}^{*}$ & $\begin{array}{c}\text { Gas Yield, } \\
\text { mol gas/ } \\
\text { mol Np }\end{array}$ & $\begin{array}{c}\text { Gas } \\
\text { mol gas } \\
\text { mol Np/min }\end{array}$ & $\begin{array}{c}\text { scfm/ } \\
\text { kg oxide }\end{array}$ \\
\hline 0 & 38 & 24.2 & 0.0 & 0.000 & & \\
\hline 4 & 44 & 45 & 5.5 & 0.008 & 0.002 & 0.006 \\
\hline 7 & 48 & 60.4 & 9.2 & 0.014 & 0.002 & 0.005 \\
\hline 10 & 53 & 73 & 13.7 & 0.021 & 0.002 & 0.007 \\
\hline 11 & 56 & 79.4 & 16.5 & 0.025 & 0.004 & 0.012 \\
\hline 13 & 65 & 88.7 & 24.8 & 0.038 & 0.006 & 0.018 \\
\hline 15 & 94 & 94.2 & 51.4 & 0.079 & 0.020 & 0.059 \\
\hline 17 & 145 & 96.9 & 98.6 & 0.151 & 0.036 & 0.104 \\
\hline 19 & 181 & 98 & 132.0 & 0.202 & 0.026 & 0.074 \\
\hline 21 & 215 & 98.8 & 163.7 & 0.251 & 0.024 & 0.070 \\
\hline 23 & 246 & 99.5 & 192.7 & 0.295 & 0.022 & 0.064 \\
\hline 25 & 268 & 100 & 213.3 & 0.327 & 0.016 & 0.046 \\
\hline 27 & 285 & 100 & 229.3 & 0.351 & 0.012 & 0.035 \\
\hline 29 & 298 & 101 & 241.5 & 0.370 & 0.009 & 0.027 \\
\hline 31 & 307 & 100 & 250.0 & 0.383 & 0.006 & 0.019 \\
\hline 36 & 314 & 99.8 & 256.6 & 0.393 & 0.002 & 0.006 \\
\hline 46 & 321 & 99.8 & 263.2 & 0.403 & 0.001 & 0.003 \\
\hline 54 & 330 & 100 & 271.7 & 0.416 & 0.002 & 0.005 \\
\hline 60 & 330 & 100 & 271.7 & 0.416 & 0.000 & 0.000 \\
\hline 61 & 258 & 100 & 203.9 & Gas Samples & lled & \\
\hline 113 & 258 & 100 & 203.9 & & & \\
\hline 160 & 258 & 100 & 203.9 & & & \\
\hline
\end{tabular}

